Published in final edited form as:

ChemMedChem. 2014 November ; 9(11): 2463-2474. doi:10.1002/cmdc.201402235.

\title{
Position and Length of Fatty Acids Strongly Affect Receptor Selectivity Pattern of Human Pancreatic Polypeptide Analogues
}

\author{
Veronika Mäde Dr. ${ }^{a}$, Kathrin Bellmann-Sickert ${ }^{\mathrm{a}}$, Anette Kaiser ${ }^{\mathrm{a}}$, Jens Meiler Prof. Dr. ${ }^{\mathrm{b}}$, and \\ Annette G. Beck-Sickinger Prof. Dr. ${ }^{a}$ \\ anstitute of Biochemistry, Faculty of Biosciences, Pharmacy and Psychology Universität Leipzig, \\ Brüderstraße 34, 04103 Leipzig (Germany), Fax: (+ 49) 341-97-36909 \\ ${ }^{\text {b} C e n t e r ~ f o r ~ S t r u c t u r a l ~ B i o l o g y, ~ V a n d e r b i l t ~ U n i v e r s i t y, ~ 5144 B ~ B i o s c i / M R B I I I, ~} 465$ 21st Ave. South, \\ Nashville, TN 37232-8725 (USA)
}

\begin{abstract}
Pancreatic polypeptide (PP) is a satiety-inducing gut hormone targeting predominantly the $\mathrm{Y}_{4}$ receptor within the neuropeptide Y multiligand/multireceptor family. Palmitoylated PP-based ligands have already been reported to exert prolonged satiety-inducing effects in animal models. Here, we suggest that other lipidation sites and different fatty acid chain lengths may affect receptor selectivity and metabolic stability. Activity tests revealed significantly enhanced potency of long fatty acid conjugates on all four $\mathrm{Y}$ receptors with a preference of position 22 over 30 at $\mathrm{Y}_{1}$, $\mathrm{Y}_{2}$ and $\mathrm{Y}_{5}$ receptors. Improved $\mathrm{Y}$ receptor selectivity was observed for two short fatty acid analogues. Moreover, $\left[\mathrm{K}^{30}\right.$ (E-Prop) $] \mathrm{hPP}_{2-36}(\mathbf{1 5})$ displayed enhanced stability in blood plasma and liver homogenates. Thus, short chain lipidation of hPP at key residue 30 is a promising approach for anti-obesity therapy because of maintained selectivity and a sixfold increased plasma half-life.
\end{abstract}

\section{Keywords}

lipidation; pancreatic polypeptide; receptors; selectivity; therapeutic peptides

\section{Introduction}

The pancreatic polypeptide (PP) is a hormone that is secreted by the pancreatic islets in response to meal ingestion proportionally to caloric intake. ${ }^{[1]}$ It mediates its biological function by a rhodopsin-like G protein-coupled receptor (GPCR), the human $\mathrm{Y}_{4}$ receptor $\left(\mathrm{hY}{ }_{4} \mathrm{R}\right)$. This peripheral gut-derived peptide can act either indirectly by gut vagal signals to higher centers in the brainstem or directly at its native target, which is expressed in the hypothalamus and brainstem of the central nervous system. Circulating PP can enter parts of the blood-brain barrier in the area postrema that is located in the dorsal vagal complex within the brainstem. ${ }^{[2]}$ Activation of the $\mathrm{hY}_{4} \mathrm{R}$, which is mainly expressed in the brain and

Correspondence to: Annette G. Beck-Sickinger, Prof. Dr..

Supporting information for this article is available on the WWW under http://dx.doi.org/10.1002/cmdc.201402235 
gastrointestinal tract ${ }^{[3]}$ leads to suppression of appetite and food intake as well as delayed gastric emptying and motility ${ }^{[2 \mathrm{~b}]}$ It has been shown that peripheral administration of PP reduces appetite and food intake in mice ${ }^{[4]}$ as well as in healthy[ ${ }^{[5]}$ and morbidly obese humans. ${ }^{[6]}$ Accordingly, PP represents an important regulator of feeding behavior and energy homeostasis.

PP belongs to the neuropeptide Y (NPY) hormone/receptor-family, which consists of three 36 amino acid peptide ligands, named NPY, peptide YY (PYY) and PP that interact with four receptors in humans, $h Y_{1} R, h Y_{2} R, h Y_{4} R$ and $h Y_{5} R .{ }^{[7]}$ These structurally related $\mathrm{Y}$ receptors are differently expressed throughout the human body and bind the ligands with different preferences. PP predominantly targets the $h Y_{4} R$, whereas $h Y_{1} R$ and $h Y_{2} R$ show low PP binding, and the $h \mathrm{Y}_{5} \mathrm{R}$ exhibits only moderate affinity for PP. NPY and PYY address $h Y_{1} R, h Y_{2} R$ and $h Y_{5} R$ with nanomolar affinity. Different effects have been reported for hYR with respect to appetite regulation. While orexigenic effects (stimulation of hunger) are conveyed by central $h \mathrm{Y}_{1} \mathrm{R}$ and $\mathrm{hY} \mathrm{Y}_{5} \mathrm{R}$, anorexigenic effects (induction of satiety) are transmitted by peripheral and central $h Y_{2} R$ and $h Y_{4} R \cdot{ }^{[2 a, 8]}$ Thus, exploiting the satiety hormone $\mathrm{PP}$ by selective activation of either the $\mathrm{hY}{ }_{2} \mathrm{R}$ or the $\mathrm{hY}{ }_{4} \mathrm{R}$ is a favorable approach for anti-obesity therapy ${ }^{[9]}$ in the context of the epidemically growing health problem of obesity and overweight, as well as associated disorders such as cardiovascular diseases and diabetes mellitus. ${ }^{[10]}$

Apart from many advantages of peptide drugs like their high specificity and activity, rare toxic degradation and in vivo predictability, they are therapeutically restricted by their low bioavailability owing to rapid proteolytic degradation and short circulation times. ${ }^{[11]}$ Hence, for effective medication, the short-acting pharmacokinetic properties of $\mathrm{PP}^{[1,12]}$ have to be improved. Among the versatile established strategies to modulate plasma half-lives of potential peptide drugs, ${ }^{[13]}$ covalent modification with fatty acids (lipidation) has come into focus during the last years. ${ }^{[14]}$ Hydrophobic moieties lead to reversible, high-affinity binding to human serum albumin, which shields and transports the acylated compounds throughout the body leading to prolonged activity profiles. ${ }^{[15]}$

Up to now, only few studies investigated the critical size of the fatty acid or the influence of positioning. ${ }^{[16]}$ Both factors, however, are important for efficient development of peptide drugs with high selectivity and increased bioavailability. Hence, individual residues that might not contribute to receptor interaction were selectively replaced and modified according to the comparative model of $\mathrm{hY}_{4} \mathrm{R}$ binding $\mathrm{PP},{ }^{[17]}$ and two positions were chosen for systematic modification with various saturated fatty acids. Independent of position and lipid, all analogues maintained high activity for $\mathrm{hY}_{4} \mathrm{R}$, which confirms the suitability of the ligand-receptor model used for this type of experiments. Interestingly, not only the position but also the length of the fatty acid dramatically influenced receptor selectivity and partly led to an increase in potency for other receptor subtypes. Moreover, pronounced resistance to proteolytic degradation was observed for a highly $\mathrm{hY}_{4} \mathrm{R}$-preferring agonist equipped with a propanoic acid, which is comparable to the related palmitoyl variant and suggests that also short-chain fatty acid peptide conjugates might be likely drug candidates in the future. 


\section{Results}

\section{Identification of best position for modification}

With the help of a recently described comparative $3 \mathrm{D}$ model of $\mathrm{hY}{ }_{4} \mathrm{R}$ bound to $\mathrm{PP},{ }^{[17]}$ accessible residues that might not contribute to ligand-receptor interaction were identified for modification (Figure 1). Positions in close proximity to the C-terminal RPRY-NH $\mathrm{NH}_{2}$ sequence that is important for binding and activation ${ }^{[18]}$ as well as residues, which are not proposed to be part of the peptide binding pocket, were chosen for modification with lysine$\gamma$-glutamyl fatty acid moieties in order to protect the peptide from fast degradation. Lipopeptides were accessible by solid-phase peptide synthesis (SPPS) ${ }^{[11 \mathrm{~b}, 19]}$ applying the 9-fluorenylmethoxycarbonyl (Fmoc)/tert-butyl ( $t \mathrm{Bu}$ ) orthogonal protecting group strategy. This method allowed the selective on-resin modification at distinct amino acid positions, which have been substituted with Lys, a $\gamma$-glutamyl linker and the desired saturated fatty acids. ${ }^{[20]}$ In a first step, the influence of the acylation site on $\mathrm{hY}_{4} \mathrm{R}$ affinity was validated. Therefore, hPP was modified with palmitic/hexadecanoic acid (Pam) at $\mathrm{Gln}^{16}, \mathrm{Ala}^{22}$ and $\mathrm{Met}^{30}$ inside the reported a-helix of the peptide. ${ }^{[21]}$ In addition, $\mathrm{Tyr}^{7}$ located within the polyL-proline type II helix as well as $\mathrm{Glu}^{4}$ in the N-terminal part of hPP represented further modification sites (Figure 1). Since the $\mathrm{N}$ terminus does not contribute to receptor binding, ${ }^{[18 b]}$ it was labeled with 5(6)-carboxyfluorescein (CF) for this first set of peptides, enabling the possibility of supplementary biological experiments. All CF-tagged palmitoylated hPP analogues were prepared in sufficient amounts and purities (see Supporting information, Table 1). In order to identify the most suitable modification sites for peptide lipidation, CF-labeled hPP variants palmitoylated at position 4 (2), 7 (3), 16 (4), 22 (5), 30 (6) as well as CF-hPP (1) as wild-type control were tested in radioligand binding assays. As shown in Figure 2a, high specific binding was observed for control peptide $\mathbf{1 b}$ (90\%), but also compounds 5 (84\%) and $\mathbf{6}(83 \%)$ displayed high specific binding that was not statistically different from CF-hPP (1) $)$. In contrast, the remaining three compounds, acylated at positions $4(2), 7(3)$ and $16(4)$ exhibited significantly reduced specific $\left[{ }^{3} \mathrm{H}\right]-\mathrm{hPP}$ binding (2: 37\%, 3: 67\%, 4: 36\%). Compounds 3, 5 and $\mathbf{6}$ were further tested for competitive displacement using an appropriate concentration range of cold ligand in presence of radioligand (Figure $2 \mathrm{~b}$ ). The determined $\mathrm{IC}_{50}$ values (1b: $3.0 \mathrm{~nm}, \mathbf{3 :} 401 \mathrm{~nm}, \mathbf{5 :} 8.6 \mathrm{~nm}, \mathbf{6}$ : $14.9 \mathrm{~nm}$ ) gave evidence that residues 22 and 30 were most suitable for acylation with fatty acids with only modestly elevated $\mathrm{IC}_{50}$ values. In contrast, $\mathbf{3}$ showed more than 100 -fold loss in affinity in comparison to control peptide $\mathbf{1 b}$.

\section{Comparison of different fatty acids}

In the next step, truncated $\mathrm{hPP}_{2-36}$ lacking a dipeptidyl peptidase IV (DPP-IV) cleavage site ${ }^{[18 b]}$ was modified at $\mathrm{Ala}^{22}$ or $\mathrm{Met}^{30}$ (Figure 1b, 1c), respectively, with propanoic acid (Prop), caprylic/octanoic acid (Capr), lauric/dodecanoic acid (Laur), Pam or arachidic/ eicosanoic acid (Ara). A slightly altered synthesis strategy was applied (Scheme 1a). ${ }^{[20]}$ Table 1 shows the full analytical characterization of all lipidated $\mathrm{hPP}_{2-36}$ conjugates. High purities and an increase in hydrophobicity attributed to fatty acid length were examined by two independent reversed-phase high-performance liquid chromatography (RPHPLC) systems, while their identity was confirmed applying matrix-assisted laser/desorption ionization-time of flight mass spectrometry (MALDI-TOF MS). Preparation on solid 
support in $15 \mu \mathrm{mol}$ or $7.5 \mu \mathrm{mol}$ scale resulted in appropriate quantities (Table 1).

Subsequently, the lipidated $\mathrm{hPP}_{2-36}$ conjugates were analyzed with respect to their biological functionality and selectivity. Signal transduction experiments were performed with COS-7 cells stably co-expressing one of the four hYR and a chimeric $\mathrm{G}_{\mathrm{i}, \mathrm{q}}$ protein ${ }^{[23]}$ to allow robust signal readout via $\left[{ }^{3} \mathrm{H}\right]$-inositol phosphates (IP). A summary of the obtained concentration-response curves for $\mathrm{hY}_{4} \mathrm{R}$ activation by the modified $\mathrm{hPP}_{2-36}$ compounds is illustrated in Figure 3, while numerical data can be found in Table 2. The native ligand hPP has an inherent activity in the low-nanomolar range (1a: $\left.\mathrm{EC}_{50}=1.3 \mathrm{nM}\right)$, which is in accordance with the literature ${ }^{[17]}$ More importantly, the high potency is not affected by any lipidation. This is reflected in similar $\mathrm{EC}_{50}$ values and full efficacies (Figure 3, Table 2) for all analogues acylated at position 22 and 30 . So, the fatty acid chain length neither has beneficial nor detrimental effects on $\mathrm{hY}_{4} \mathrm{R}$ activation.

\section{Loss of subtype preference by long fatty acid modification}

Next, IP accumulation assays with $\mathrm{hY} \mathrm{Y}_{1} \mathrm{R}$-expressing COS-7 cells were performed in order to evaluate the activity potential of the lipopeptides at the structurally related $\mathrm{Y}$ receptor subtype that exhibits opposing effects (stimulation of food intake). As shown in Figure 3, both non-lipidated precursor peptides $\left[\mathrm{K}^{22}\right] \mathrm{hPP}_{2-36}\left(\mathbf{8}: \mathrm{EC}_{50}=51.4 \mathrm{nM}\right)$ and $\left[\mathrm{K}^{30}\right] \mathrm{hPP}_{2-36}$ (14a: $\mathrm{EC}_{50}>1000 \mathrm{~nm}$ ) exhibit remarkably little activation of $\mathrm{hY}_{1} \mathrm{R}$ compared to the native ligand NPY (7: $\left.\mathrm{EC}_{50}=3.5 \mathrm{~nm}\right)$. Interestingly however, introduction of lysine at position 22 led to increased inherent $h \mathrm{~h}_{1} \mathrm{R}$ potency of $\mathrm{hPP}_{2-36}$ analogues with $\mathrm{EC}_{50}$ values of $\left[\mathrm{K}^{30}\right] \mathrm{hPP}_{2-36}$ being 15 -fold lower than for $\left[\mathrm{K}^{22}\right] \mathrm{hPP}_{2-36}$ (Table 2). At both locations, a substantial decrease in activity occurred for the short fatty acid conjugates (E-Prop, E-Capr), whereas from a chain length of 12 carbon atoms (E-Laur) potency was regained.

Interestingly, palmitoylation and arachidoylation led to considerably more active analogues compared to their respective predecessors. Additionally, the potencies for compounds $\mathbf{1 2}$ and $\mathbf{1 3}$ as well as 18a and $\mathbf{1 9}$ are only 5- to 20-fold reduced compared to the native ligand NPY (7) at this receptor. Overall, the $\mathrm{hY} \mathrm{R}_{1} \mathrm{R}$ activity of $\left[\mathrm{K}^{30}\right] \mathrm{hPP}_{2-36}$ lipidated conjugates was lower compared to the compounds modified at position 22 (Figure 3, Table 2).

Signal transduction studies at anorexigenically acting $\mathrm{hY}_{2} \mathrm{R}$ (Figure 3, Table 2) revealed a similar pattern as observed for the $h \mathrm{Y}_{1} \mathrm{R}$. However, albeit the potency of the native ligand NPY $\left(7: \mathrm{EC}_{50}=0.3 \mathrm{~nm}\right)$ was about one order of magnitude higher than for the $\mathrm{hY}_{1} \mathrm{R}$, the precursor peptides yielded potencies comparable to $\mathrm{hY}_{1} \mathrm{R}$. Again, a shift from lower to higher potency with extension of fatty acid length was observed (Table 2), with short fatty acids increasing the specificity of the ligand for the $\mathrm{hY}_{4} \mathrm{R}$, and long fatty acids increasing activity on $\mathrm{hY}$ receptors in general. Most notably, $\left[\mathrm{K}^{22}\right] \mathrm{hPP} 2-36$ lipidated with palmitic acid (12: $\left.\mathrm{EC}_{50}=1.7 \mathrm{nM}\right)$ and arachidic acid $\left(13: \mathrm{EC}_{50}=0.9 \mathrm{~nm}\right)$ were identified as highly active ligands at the $\mathrm{hY}_{2} \mathrm{R}$, showing potencies in the range of the native ligand NPY (7) and being 40- and 75-fold, respectively, more potent than the parent peptide $\mathbf{8}$.

Finally, activity tests at the $\mathrm{h} \mathrm{Y}_{5} \mathrm{R}$ exhibited a marginally different activation profile of the acylated conjugates (Figure 3, Table 2). This receptor subtype seemed to be less selective towards its native ligand NPY (7: $\left.\mathrm{EC}_{50}=4.3 \mathrm{~nm}\right)$ since both precursor peptides $[\mathrm{K}] \mathrm{hPP}_{2-36}$ possessed high activities in the low-nanomolar range $\left(\mathbf{8}: \mathrm{EC}_{50}=6.1 \mathrm{nM}, \mathbf{1 4 a}: \mathrm{EC}_{50}=23.9\right.$ 
nM). While modification with short fatty acids again provoked potency decrease, activity was enhanced with longer fatty acids as observed for $h \mathrm{Y}_{1} \mathrm{R}$ and $\mathrm{hY}_{2} \mathrm{R}$ and even resulted in the first hPP-based $\mathrm{hY}_{5} \mathrm{R}$ agonists with even better potencies than NPY (12: $\mathrm{EC}_{50}=1.9 \mathrm{nM}, \mathbf{1 8 a}$ : $\left.\mathrm{EC}_{50}=1.6 \mathrm{~nm}, 13: \mathrm{EC}_{50}=0.8 \mathrm{~nm}, 19: \mathrm{EC}_{50}=0.6 \mathrm{~nm}\right)$. Moreover, activity comparison of the shorter fatty acid hPP analogues (E-Prop, E-Capr) at the two distinct positions reflected about 10 -fold difference in $\mathrm{hY}_{5} \mathrm{R}$ activation compared to any other peptide, indicating again a preference of the receptor for position 22 over 30 (Table 2).

\section{Structural impairments are not the reason for the altered activity pattern}

Since long-chain fatty acid analogues differed in their behavior towards hYR selectivity relative to short- or medium-chain fatty acid conjugates, we hypothesized that conformational changes could be the reason. We performed circular dichroism (CD) spectroscopy in order to determine potential structural influences or changes induced by different fatty acid moieties. Nearly all hPP analogues lipidated at position 22 or 30 displayed typical features of an a-helix in CD spectra (see Supporting information, Figure 1a,b). Negative Cotton effects at 208 and $222 \mathrm{~nm}$ as well as a large maximum at around 190 $\mathrm{nm}$ were observed. Surprisingly, compounds acylated with the longest fatty acid (E-Ara) revealed disturbed structures with more $\beta$-sheet-like characteristics. ${ }^{[24]}$ The amounts of secondary structure were quantified by Dichroweb using K2D analysis (Table 1). ${ }^{[22]}$ These calculations suggested that the decrease of $a$-helical proportion is stronger with increase in fatty acid length at position 22 opposed to residue 30 . Exclusively, arachidoylated hPP compounds were not capable to form the classical PP structure in solution. In order to prove the possibility that these compounds fold only upon approaching the cell membrane, CD spectra were recorded in the presence of $20 \mathrm{~mm}$ sodium dodecylphosphate (SDS). Indeed, hPP analogues $\mathbf{1 3}$ and $\mathbf{1 9}$ revealed an increased fraction of a-helix comparable to wild type in this membrane-mimicking environment (see Supporting information, Figure 1c, and Table 1). These results indicated that in solution only fatty acids of very long chain length bias the a-helicity of the ligand, probably due to changes in hydrophobicity of the peptide microenvironment. Capturing the hydrophobic moiety in a detergent or membrane environment can thus restore secondary structure. In general, however, these data suggested that the global peptide backbone orientation was not impaired by lipidation, and, thus, direct receptor interaction seems to affect receptor recognition.

\section{In vitro stability}

To underline the proposed therapeutic potential of the new $\mathrm{hY}_{4} \mathrm{R}$-preferring agonists by the fatty acid moieties, degradation was investigated in human blood plasma (Figure 4a) and porcine liver homogenates (Figure $4 \mathrm{~b}$ ). Two selective $\mathrm{hY}_{4} \mathrm{R}$ ligands $\left[\mathrm{K}^{30}\right.$ (E-Prop) $] \mathrm{hPP} \mathrm{P}_{2-36}$ $(\mathbf{1 5 b})$ and $\left[\mathrm{K}^{30}(\mathrm{E}-\mathrm{Capr})\right] \mathrm{hPP} 2-36(\mathbf{1 6} \mathbf{b})$, the palmitoylated variant $\mathbf{1 8 b}$ and the control peptide $\mathbf{1 4 b}$ were equipped with an additional $\mathrm{N}$-terminal fluorescent dye, 6carboxytetramethylrhodamine (TAMRA) (Scheme $1 \mathrm{~b}$ ), allowing peptide-specific detection of degradation by RP-HPLC. Analogue 20, which was fluorescently labeled at the side chain of Lys ${ }^{30}$, served to detect $\mathrm{N}$-terminally degraded peptides (Table 3 ).

As depicted in Figure 4a, all investigated compounds displayed a decay of intact peptide in human blood plasma over $144 \mathrm{~h}$. Both precursor peptides 14b and 20 revealed similar 
degradation with comparable half-lives of around $100 \mathrm{~h}$ (Table 4). The similar amount of Nand side chain fluorescently labeled precursor peptide underlines the suitability of the experimental setup and implies that peptide stability is not affected by the fluorophore TAMRA itself. As expected, the long-chain lipopeptide 18b showed most pronounced resistance to proteolytic degradation with more than 10 -fold increased half-life $\left(\mathbf{1 8 b}: t_{1 / 2}=\right.$ $1088.1 \pm 282.4 \mathrm{~h})$ compared to the control peptide $\left(\mathbf{1 4 b}: t_{1 / 2}=84.7 \pm 2.3 \mathrm{~h}\right)$. Surprisingly, degradation rates were faster for the longer E-Capr variant (16b: $\left.t_{1 / 2}=281.3 \pm 26.7 \mathrm{~h}\right)$ relative to the shorter E-Prop compound (15b: $t_{1 / 2}=473.6 \pm 17.3 \mathrm{~h}$, see also Table 4). To evaluate the stability in high enzyme and low albumin concentration, metabolism in homogenized liver extracts was monitored over $48 \mathrm{~h}$. Again, all analogues were degraded over time (Figure $4 \mathrm{~b}$ ), and with respect to the control peptides $\mathbf{1 4 b}$ and $\mathbf{2 0}$, no significant differences between their half-lives were observed (Table 4). Notably, for the peptide modified with the shortest fatty acid (15b) a considerably slower degradation was determined, which is also reflected in significantly increased half-life (15b: $t_{1 / 2}=46.7 \pm 6.6$ h) compared to the parent peptide (14b: $\left.t_{1 / 2}=11.0 \pm 0.4 \mathrm{~h}\right)$. In contrast, no improved in vitro stability was determined for the E-Capr (16b) and the E-Pam (18b) peptide analogues although they contained a longer fatty acid moiety (Figure 4b, Table 4).

In summary, the E-Pam $\mathrm{hPP}$ variant $\mathbf{1 8 b}$ was the most stable lipopeptide in plasma followed by the E-Prop and E-Capr compounds. Thus, the E-Prop-modified hPP variants $\mathbf{1 5 a}$ and $\mathbf{1 5 b}$ could be identified as a $\mathrm{hY}{ }_{4} \mathrm{R}$ selective ligand with improved half-lives both in human blood plasma as well as in porcine liver homogenates.

\section{Discussion}

Lipidation has already been highlighted as a successful and prospective strategy to modulate plasma half-life and to improve bioavailability of several peptides ${ }^{[14]}$ including hPP. ${ }^{[20]}$ In a previous study, an hPP ligand has been developed that contained palmitic acid at lysine residue 13 equipped with a $\gamma$-glutamyl spacer. This analogue specifically targeted not only the $\mathrm{hY}_{4} \mathrm{R}$ but also the $\mathrm{hY}_{2} \mathrm{R}^{[25]}$ and showed anorexigenic effects in mice as well as increased circulation times. More recently, $\mathrm{hY}_{2} \mathrm{R} / \mathrm{hY}{ }_{4} \mathrm{R}$-targeting $\mathrm{hPP}$ analogues with modification of Prop, Capr and Pam at position 22 were investigated with respect to their selectivity, stability and most notably, for their internalization. In this study, merely the long-chain Pam variant revealed significantly improved plasma stability, whereas shorter-chain lipopeptides showed only slightly slower metabolic degradation. ${ }^{[20 \mathrm{~b}]}$ However, the development of ligands with a preference of the $\mathrm{hY}_{4} \mathrm{R}$ over the $\mathrm{hY}_{2} \mathrm{R}$ is desirable because activation of the latter in central and diverse peripheral regions might lead to unwanted side effects in therapy. $\mathrm{Y}_{2} \mathrm{R}$ targeting could worsen retinopathy in diabetic patients ${ }^{[26]}$ or induce cancer growth and vascularization. ${ }^{[27]}$ Furthermore, the $\mathrm{hY}_{2} \mathrm{R}$-preferring $\mathrm{PYY}_{3-36}$, which is the naturally cleaved form of PYY, is also reported to cause nausea and fullness, especially at high dosages. ${ }^{[28]}$

In the present study, the therapeutically interesting gut hormone hPP was chemically modified by lipidation with albumin-binding fatty acids of different chain length at diverse positions in order to improve selectivity and stability features. To overcome potential side effects and cross-reactivity, the impact of the peptide substitution site and fatty acyl chain 
length on target specificity and neuropeptide $\mathrm{Y}$ receptor subtype selectivity was investigated by signal-transduction as well as conformational studies. All designed peptides were accessible by SPPS and could be obtained in high purities and good yields.

To find an appropriate acylation position, five hPP analogues were generated by palmitoylation at different parts of their secondary structure. To date, the model of a hairpinlike secondary structure of PP (PP-fold) composed of an N-terminal type II poly-L-proline helix (residues 1-8), followed by a $\beta$-turn (residues 9-12), an extended amphiphatic a-helix (residues 13-30) and a relatively flexible C-terminal region (residues 31-36) is well established in literature. ${ }^{[21 a, 29]}$ It is known that the characteristic PP-fold leads to correct orientation of the $\mathrm{C}$-terminal hexapeptide and the $\mathrm{N}$-terminal amino acids of PP, thereby mediating receptor recognition. ${ }^{[18 \mathrm{a}, 21 \mathrm{a}\rfloor}$ The location of the chosen residues for modification ranged from the poly-L-proline type II helix to the a-helix. ${ }^{[18 b, 21 b \backslash}$ For analogues acylated at position $22(\mathbf{5})$ and $30(\mathbf{6})$, located at the center and the C-terminal end of the PP-a-helix, respectively, high-affinity binding was determined. On the contrary, lipidation at residues 4 , 7 and 16 showed a loss in affinity. Interestingly, position 4 was not suitable for modification although for NPY it is known as a well-tolerated derivatization site. ${ }^{[30]}$ These observations suggest diverse active structures and binding modes of both neuropeptides. Residues $\mathrm{Tyr}^{7}$ and $\mathrm{Gln}^{16}$, found in more central parts of the peptide, might also be important for stabilization of the biologically important PP-fold, which is reflected in low $\mathrm{hY}_{4} \mathrm{R}$-binding capacities. The 3D comparative model of the $\mathrm{hY}_{4} \mathrm{R}$ binding $\mathrm{hPP}^{[17]}$ suggested C-terminal residues to be appropriate for substitution, although some positions in this region $\left(\mathrm{Tyr}^{27}\right.$, $\mathrm{Arg}^{33}$ and $\mathrm{Arg}^{35}$ ) are described to actively interact with transmembrane residues of the $\mathrm{hY}_{4} \mathrm{R} \cdot{ }^{[17,31]}$ The retained $\mathrm{hY}{ }_{4} \mathrm{R}$ affinity of peptides with modification at position 30 confirmed this proposed orientation in the binding pocket.

The predecessor for the following studies, $\mathrm{hPP}_{2-36},{ }^{[32]}$ lacks the first amino acid $\mathrm{Ala}^{1}$, thus representing a more stable peptide compared to $\mathrm{hPP}_{1-36}$ that is a substrate of the aminopeptidase DPP-IV. ${ }^{[18 \mathrm{~b}]}$ Likewise, it has been reported that it constituted an improved selectivity window since the $\mathrm{hY}{ }_{1} \mathrm{R}$ required the first amino acid for activation. ${ }^{[18 \mathrm{~b}]}$ Most importantly, a single subcutaneous administration of $\mathrm{hPP}_{2-36}$ was shown to significantly suppress food intake in mice over an $8 \mathrm{~h}$ period, demonstrating its high anorexigenic potential. ${ }^{[18 b]}$ Hence, novel peptides substituted with Lys- $\gamma$ Glu and natural lipophilic building blocks containing two (Prop), seven (Capr), 11 (Laur), 15 (Pam) or 19 (Ara) hydrocarbon moieties at the most promising amino acid positions 22 and 30 were prepared. CD studies confirmed that hPP and the related peptides PYY and NPY bear an intense $a-$ helical character. ${ }^{[20 a, 33[} \mathrm{CD}$ spectroscopy of the diverse lipidated analogues revealed no significantly altered helix formation in accordance to a previous report, ${ }^{[20 b]}$ except for derivatization with Ara, although modifications were located in the a-helix of PP. These results suggested that the lipophilic groups are oriented away from the hydrophobic peptide core $^{[21 a]}$ without altering the global peptide backbone conformation. For the investigated analogues, a-helix formation was somewhat more impaired upon modification with increasing fatty acid length at position 22 in contrast to position 30 . This reflects an influence of the location of the substitution on secondary structure formation. However, especially the long-chain fatty acids might influence single side chain orientation or intra- 
and intermolecular interactions, which has been published previously for a short NPY analogue containing a hydrophobic modification. ${ }^{[34]}$ Interestingly, the longest hydrophobic modification (Ara) exhibited strongly reduced helicity in solution, which was not observed in the presence of detergent-containing buffer. Thus, arachidoyl compounds may fold into their bioactive secondary structure once they approach membranes. Lerch et al. ${ }^{[21 b]}$ investigated bovine PP (bPP) by NMR studies in membrane-bound and solution state. They showed that the slightly flexible peptide $\mathrm{N}$ terminus was folded back in solution, while in a membrane-mimicking environment that region interacted with phospholipids. ${ }^{[21 b]}$ These data support the relatively flexible and dynamic conformation of the individual folded compartments, when the peptide changes from solution to a membrane-bound state. However, we could not find a general stabilization of the peptide secondary structure by acylation as shown by Poschner et al. ${ }^{[35]}$

Extensive signal transduction studies of all $\mathrm{hPP}_{2-36}$ conjugates lipidated at position 22 or 30 , respectively, disclosed an overall altered receptor selectivity profile depending on the used acylation moiety. While all lipopeptides retained $\mathrm{hY}_{4} \mathrm{R}$ recognition, those modified with short-chain fatty acids revealed higher, but those with longer-chain fatty acids lower subtype specificity. Furthermore, these observations were more pronounced for modifications at residue 30 opposed to 22 since the inherent hYR selectivity profile of the $\left[\mathrm{K}^{30}\right] \mathrm{hPP}_{2-36}$ was higher compared to $\left[\mathrm{K}^{22}\right] \mathrm{hPP}_{2-36}$ As a consequence, on the one hand, two novel short-chain fatty acid analogues with improved $\mathrm{hY}_{4} \mathrm{R}$ preference in comparison to the natural ligand $\mathrm{hPP}$ (15a, 16a) were identified. On the other hand, the first hPP-based peptide conjugates acylated with long-chain fatty acids $(\mathbf{1 2}, \mathbf{1 3}, \mathbf{1 8 a}, \mathbf{1 9})$ were found that have the ability to recognize and activate all four hYR subtypes at low- to sub-nanomolar potency.

Interestingly, conformational differences of the lipidated compounds were not found to be significantly affected by the variably sized hydrophobic entities. Thus, an altered global backbone orientation might not be the reason for the unexpected receptor selectivity profiles. So far, it is known that NPY and PP possess different preferences at distinct hYR, although $\mathrm{hY}_{4} \mathrm{R}$ and $\mathrm{hY}{ }_{1} \mathrm{R}$ share high sequence identities. ${ }^{[7]}$ Additionally, diverse docking of neuropeptide $\mathrm{YR}$ ligands to $\mathrm{hY} /{ }_{1} \mathrm{R}$ opposed to $\mathrm{hY}{ }_{2} / 5 \mathrm{R}$ has been proposed. ${ }^{[31]}$ Different membrane-bound structures of the native YR ligands NPY and $\mathrm{PP}^{[21 \mathrm{~b}]}$ suggest diverse binding modes at the hYR that might be influenced by lipophilic groups at the ligand site. For modification with long fatty acids, hydrophobic peptide conjugates might increase local peptide concentrations at the receptor or membrane proximity, accumulate and impart superior activities, as concluded from former studies. ${ }^{[16 c]}$ However, this assumption would also speak for improved $\mathrm{hY}_{4} \mathrm{R}$ activation for longer fatty acid ligands, which was not observed in our experiments. In view of the literature, many authors report about enhanced agonistic effects towards diverse targets ${ }^{[16 c, 36]}$ but also slightly disturbed or unaffected efficacy in correlation to conjugation with fatty acids. ${ }^{[16 a, d, e]}$ Thus, the reason for the unaltered activity towards the native $\mathrm{hY}_{4} \mathrm{R}$ could be that the $\mathrm{hPP}$ ligands have high affinities leading to fast target binding independent of whether the agonists are in solution or attached to the cell membrane. Steady receptor occupancy may thus prevent membrane-accumulated ligands from receptor interaction. In contrast, $\mathrm{hY}_{2} \mathrm{R}$ and $\mathrm{hPP}$ have a reduced affinity, leading to an increased influence of the elevated local ligand concentration in proximity to the receptor due to membrane binding. Another possibility to explain the diversely improved 
potency might be that hydrophobic positions within the individual binding pockets in the $h Y_{1} R, h Y_{2} R$ or $h Y_{5} R$ that are normally not addressed by the native ligands become accessible by long-chain fatty acid analogues and contribute to binding. Apart from that, all hPP $_{2-36}$ peptides lipidated with E-Prop $(\mathbf{9}, \mathbf{1 5 a})$, E-Capr $(\mathbf{1 0}, \mathbf{1 6 a})$ or E-Laur $(\mathbf{1 1}, \mathbf{1 7})$ showed acylation-site-dependent high activity towards $h Y_{5} \mathrm{R}$. Nevertheless, these compounds might still be favorable $\mathrm{hY}_{4} \mathrm{R}$-selective therapeutics with respect to their application as drugs since the $\mathrm{hY}_{5} \mathrm{R}$ is solely expressed in the central nervous system, which may not be accessible for peripherally administered $\mathrm{hPP}^{[18 \mathrm{~b}]}$

The best $\mathrm{hY}_{4} \mathrm{R}$-preferring $\mathrm{hPP}$ agonists $\left[\mathrm{K}^{30}(\mathrm{E}-\mathrm{Prop})\right] \mathrm{hPP} \mathrm{P}_{2-36}(\mathbf{1 5 a})$ and $\left[\mathrm{K}^{30}(\mathrm{E}-\right.$ Capr)]hPP $2-36$ (16a) along with the E-Pam analogue (18a) were further examined for their in vitro stability in human blood plasma and porcine liver homogenates. In contrast to $\mathrm{hY}_{2} \mathrm{R} / \mathrm{hY}{ }_{4} \mathrm{R}$-addressing $\mathrm{hPP}$ peptides lipidated at position $22,{ }^{[20 \mathrm{~b}]}$ all lipopeptides of the current study significantly improved plasma half-lives that did not directly correlate to the fatty acid length. Interestingly, protection was not observed for the longer-chain fatty acid conjugates in concentrated liver homogenates, whereas the Prop variant revealed increased metabolic stabilization related to the precursor. Although PP constitutes several structural features such as C-terminal amidation ${ }^{[18 b]}$ that are beneficial in terms of degradation through enzymes, its half-life in the circulation was determined to be less than $7 \mathrm{~min} .{ }^{[1]}$ This might be due to fast excretion via the kidneys ${ }^{[18 b, 20 a]}$ or rapid proteolytic cleavage.

Basically, fatty acid acylation goes along with prolonged actions and circulation times that facilitate reversible serum albumin binding in a fatty acid length-cooperative manner. ${ }^{[15,37]}$ This successful method has broad application ${ }^{[14]}$ and already led to effective long-acting peptide drugs that are launched for diabetes treatment (Levemir and Victoza). ${ }^{[11 \mathrm{~b}]}$ Nevertheless, these results reveal that the optimal length for binding albumin might be palmitic acid, but also the very short propanoic acid revealed remarkable protection at residue 30. Interestingly, stability towards liver enzymatic digestion was only observed for the shortest lipopeptide. This could originate from low serum albumin concentrations in the liver, where albumin is just produced. However, the propanoyl entity might extend the halflife not only due to hydrophobic but also by possibly more pronounced electrostatic interactions of the carboxylate anion that is also known to contribute to albumin binding. [38]

\section{Conclusions}

In summary, two novel human pancreatic polypeptide (hPP)-derived human $\mathrm{Y}_{4}$ receptor $\left(\mathrm{hY}{ }_{4} \mathrm{R}\right)$-preferring analogues were discovered by lipidation with short-chain fatty acids. Strikingly, the propylated conjugate was more stable in blood plasma and liver homogenates compared to the precursor peptide indicating its prospective therapeutic potential as antiobesity drug. Moreover, within the substituted amino acid residues, position 22 exhibited a general preference over position 30 at $h Y_{1} R, h Y_{2} R$ and $h Y_{5} R$. The impact of variably sized covalently conjugated fatty acids on the biological profile of hPP uncovered a general selectivity pattern. For this multiligand/multireceptor system, a universal duality between selectivity and membrane targeting is proposed by using peptide lipidation. With the increase in fatty acid chain length, the ligands become more concentrated on membranes leading to faster recognition and earlier transitions to the respective receptor binding 
pockets. ${ }^{[39]}$ In contrast, shorter fatty acids might lack appropriate lipophilicity in order to significantly accumulate in the membrane environment and are thus less active. Hence, for general applications, one has to distinguish between desired drugability/membrane targeting or selectivity of chemically engineered hPP. Long-acting and highly active analogues that target receptors or other membrane proteins without the need of being subtype selective can be generated with long alkyl chains such as palmitic acid. Instead, high target specificity and consequently lower side effects might be achieved with shorter hydrocarbon chains with moderate protection at suitable modification sites.

\section{Experimental Section}

\section{Solid-phase peptide synthesis (SPPS)}

Multiple and automated SPPS was performed with a Syro I or Syro II peptide synthesizer from MultiSynTech (Witten, Germany) using plastic syringes equipped with teflon frits. Peptides that have been cleaved from the resin by trifluoroacetic acid (TFA) were identified by MALDI-TOF MS using a Microflex or Ultraflex III TOF/TOF device from Bruker Daltonics and the software FlexControl/-Analysis (version 3.0). Purity and quantity of synthesized peptides was analyzed by RP-HPLC in analytical scale by applying a Merck HPLC system equipped with a Jupiter $4 \mathrm{u}$ Proteo ( $90 \AA \AA, 4 \mu \mathrm{m}, 250 \times 4.6 \mathrm{~mm}$; Phenomenex), a

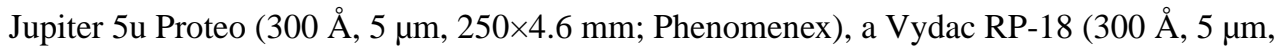
$250 \times 4.6 \mathrm{~mm}$; Grace Vydac), or a Varian-VariTide RPC column (200 ̊, $6 \mu \mathrm{m}, 250 \times 4.6 \mathrm{~mm})$. Solvents were $0.1 \%(\mathrm{~V} / \mathrm{V})$ TFA (Sigma-Aldrich) in $\mathrm{H}_{2} \mathrm{O}$ (eluent A) and $0.08 \%(\mathrm{v} / \mathrm{V})$ TFA in $\mathrm{CH}_{3} \mathrm{CN}$ (Prolabo; eluent B). Purification of raw peptides was performed with a Shimadzu preparative RP-HPLC by using the same eluents and a Jupiter 10u Proteo RP-C $\mathrm{C}_{18}(90 \AA$, $7.78 \mu \mathrm{m}, 250 \times 21.2 \mathrm{~mm}$; Phenomenex) or a Vydac RP-C 18 HPLC column (300 ̊; $10 \mu \mathrm{m}$, $250 \times 22 \mathrm{~mm}$; Grace Vydac), respectively.

Robot-assisted SPPS was performed using the Fmoc/ $t \mathrm{Bu}$ orthogonal protecting group strategy. Amino acid side chain protecting groups were as follows: trityl (Trt) for Asn, Cys and Gln; $t$ Bu for Asp, Glu, Thr and Tyr; tert-butyloxycarbonyl (Boc) for Trp; and pentamethyl-2,3-dihydrobenzofuran-5-sufonyl ( $\mathrm{Pbf}$ ) for Arg (Fmoc-amino acids purchased from Iris Biotech, Marktredwitz, Germany). Automated Fmoc deprotection was carried out with $40 \%(\mathrm{~V} / \mathrm{V})$ piperidine (Sigma-Aldrich) in $\mathrm{N}, \mathrm{N}$-dimethylformamide (DMF; Biosolve, Valkenswaard, The Netherlands) for $3 \mathrm{~min}$ and $20 \%(\mathrm{~V} / \mathrm{V})$ piperidine in DMF for $10 \mathrm{~min}$. In situ activation and coupling of Fmoc-amino acids $(0.12 \mu \mathrm{mol})$ that were dissolved to $0.5 \mathrm{~m}$ in DMF was performed with OxymaPure $(0.12 \mu \mathrm{mol}$ in DMF, 2 min pre-incubation on resin; Iris Biotech) and $N, N^{\prime}$-diisopropylcarbodiimide (DIC; $0.12 \mu \mathrm{mol}$ in DMF; Iris Biotech) twice for $30 \mathrm{~min}$.

CF-hPP (1 b), CF-[K $\left.{ }^{4}(E-P a m)\right] h P P(2), C F-\left[K^{7}(E-P a m)\right] h P P(3), C F-\left[K^{16}(E-\right.$ Pam)]hPP (4), CF-[K $\left.{ }^{22}(E-P a m)\right] h P P(5), C F-\left[K^{30}(E-P a m)\right] h P P(6)$-For synthesis of the full-length 5(6)-carboxyfluorescein (CF)-labeled peptide, automated SPPS was performed on Rink amide AM resin (Iris Biotech; $7.5 \mu \mathrm{mol}$ scale) including a $3 \mathrm{~h}$ manual coupling step of Fmoc-L-Lys(Dde)-OH $(20 \mathrm{mg}, 0.038 \mu \mathrm{mol})$ with 1-hydroxy-benzotriazole (HOBt; $5.8 \mathrm{mg}, 0.038 \mu \mathrm{mol}$; Novabiochem) and DIC (5.9 $\mu \mathrm{L} ; 0.038 \mu \mathrm{mol})$ in $100 \mu \mathrm{L}$ DMF 
at position $4(\mathbf{2}), 7(3), 16(4), 22(\mathbf{5})$ or $30(\mathbf{6})$. The $\mathrm{N}$ termini of the peptides were modified by reaction with CF (14.1 mg, $0.075 \mu \mathrm{mol}$; Sigma-Aldrich) using HOBt $(5.8 \mathrm{mg}, 0.038$ $\mu \mathrm{mol})$ and DIC $(5.9 \mu \mathrm{L}, 0.038 \mu \mathrm{mol})$ in $100 \mu \mathrm{L}$ DMF overnight. CF-polymers were cleaved by incubation with $20 \%(\mathrm{~V} / \mathrm{V})$ piperidine in $500 \mu \mathrm{L}$ DMF for $1 \mathrm{~h}$, followed by an overnight Trt-protection of CF-hydroxyl groups with trityl chloride ( $8.4 \mathrm{mg}, 0.03 \mu \mathrm{mol}$; Merck) and $N, N$-diisopropylethylamine (DIPEA; $5.3 \mu \mathrm{L}, 0.03 \mu \mathrm{mol}$; Sigma-Aldrich) diluted in $250 \mu \mathrm{L}$ $\mathrm{CH}_{2} \mathrm{Cl}_{2}$ (Biosolve). The 1-(4,4-dimethyl-2,6-dioxocyclohex-1-ylidene)ethyl (Dde)-group was removed by applying 2\% $(v / v)$ hydrazine in $1 \mathrm{~mL}$ DMF (10x; Sigma-Aldrich) for 10 min including DMF washing steps in between. Success of deprotection was determined by UV measurements of wash solutions at $301 \mathrm{~nm}$. After $3 \mathrm{~h}$ manual coupling of Fmoc-L-Glu$\mathrm{O} t \mathrm{Bu}(16.0 \mathrm{mg}, 0.38 \mu \mathrm{mol})$ applying HOBt $(5.8 \mathrm{mg}, 0.038 \mu \mathrm{mol})$ and DIC $(5.9 \mu \mathrm{L}, 0.038$ $\mu \mathrm{mol})$ in $100 \mu \mathrm{L}$ DMF, and Fmoc removal by incubation with $20 \%(v / v)$ piperidine in DMF ( $2 \times 20 \mathrm{~min})$, palmitic acid (Sigma-Aldrich) coupling $(9.6 \mathrm{mg}, 0.038 \mu \mathrm{mol})$ was performed using HOBt $(5.8 \mathrm{mg}, 0.038 \mu \mathrm{mol})$ and DIC $(5.9 \mu \mathrm{L}, 0.038 \mu \mathrm{mol})$ in $100 \mu \mathrm{L} N$-methyl-2pyrrolidone (NMP; Biosolve) for $3 \mathrm{~h}$. Cleavage from the resin was performed with TFA (450 $\mu \mathrm{L}$ ), and a scavenger mixture of 1,2-ethanedithiol (EDT; $35 \mu \mathrm{L}$; Sigma-Aldrich) and thioanisole (TA; $15 \mu \mathrm{L}$; Sigma-Aldrich) for $3 \mathrm{~h}$. Peptides were precipitated from ice-cold $\mathrm{Et}_{2} \mathrm{O}(10 \mathrm{~mL})$, washed $5 \times$ and dried in vacuo. In order to reduce partially oxidized methionine residues, compounds were re-dissolved in TFA $(1 \mathrm{~mL})$ and incubated with EDT $(16 \mu \mathrm{L})$ and bromotrimethylsilane (TMSBr; $12 \mu \mathrm{L}$; Sigma-Aldrich) for 30 min, precipitated and washed with $\mathrm{Et}_{2} \mathrm{O}(5 \times 10 \mathrm{~mL})$, dissolved in $\mathrm{H}_{2} \mathrm{O} / \mathrm{tBuOH}(1: 3, v / v)$ and finally

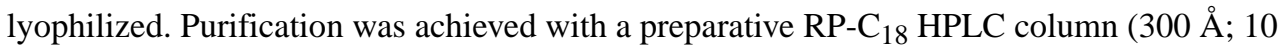
$\mu \mathrm{m}, 250 \times 22 \mathrm{~mm}$; Grace Vydac) and linear gradients of eluent B in A: $20 \%$ to $60 \%(\mathrm{~V} / \mathrm{V})$ in $40 \mathrm{~min}$ for $\mathbf{1 b}, 40 \%$ to $80 \%(\mathrm{~V} / \mathrm{V})$ in $40 \mathrm{~min}$ for peptides 2-6. Incorporation of the fluorophore and all following steps were performed in the dark. Analytical data and yields of all compounds are summarized in the Supporting information, Table 1. Calculated masses refer to the averaged isotope pattern. High deviations of measured versus calculated masses resulted from measurement in the linear mode instead of reflector mode.

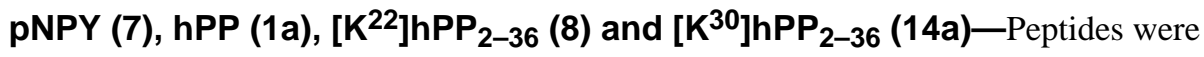
synthesized automatically using a Rink amide AM resin (15 $\mu$ mol scale), cleaved from resin with TFA $(900 \mu \mathrm{L})$ with a scavenger mixture of either TA $(50 \mu \mathrm{L})$ and $p$-thiocresol $(50 \mu \mathrm{L}$; Sigma-Aldrich) for 7, or EDT (70 $\mu \mathrm{L})$ and TA $(30 \mu \mathrm{L})$ for $\mathbf{1 a}, \mathbf{8}$ and 14a within $3 \mathrm{~h}$. After precipitation from ice-cold $\mathrm{Et}_{2} \mathrm{O}(10 \mathrm{~mL})$, peptides were washed $5 \times$ and dried in vacuo. $\mathrm{hPP}$ sequences containing oxidized methionines were reduced as mentioned above, dissolved in $\mathrm{H}_{2} \mathrm{O} / t \mathrm{BuOH}(3: 1, V / V)$ and finally lyophilized. Purification was performed with a preparative Jupiter 10u Proteo RP-C 18 HPLC column (90 А, $7.78 \mu \mathrm{m}, 250 \times 21.2 \mathrm{~mm}$; Phenomenex) using a linear gradient of $20 \%$ to $60 \%(\mathrm{~V} / \mathrm{V})$ of eluent B in A over $40 \mathrm{~min}$. Yield, purities, RP-HPLC and MALDI-TOF characterization can be found in Table 1.

[K ${ }^{22}$ (E-Prop)]hPP $2-36$ (9), [K ${ }^{22}$ (E-Capr)]hPP $2-36$ (10), [K ${ }^{22}$ (E-Laur)]hPP ${ }_{2-36}$ (11), [K $\left.{ }^{22}(E-P a m)\right] h P P_{2-36}$ (12), [K $\left.{ }^{22}(E-A r a)\right] h P P_{2-36}$ (13), [K ${ }^{30}$ (E-Prop)]hPP $2-36$ (15a),

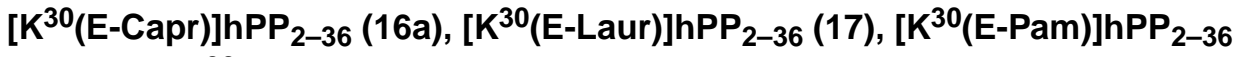
(18a) and [K $\left.{ }^{30}(E-A r a)\right] h P_{2-36}(19)$-SPPS was carried out automatically up to $\mathrm{hPP}_{21-36}(\mathbf{9 - 1 3})$ or hPP $31-36$ (15a, 16a, 17-19) on a Rink amide AM (9-12, 15a, 16a, 17, 
18a) or NovaSyn TGR R (Novabiochem) $(13,19)$ resin $(15 \mu$ mol scale). Dde-L-Lys(Fmoc)$\mathrm{OH}(40.0 \mathrm{mg}, 0.075 \mu \mathrm{mol})$ was coupled to the peptide sequence with HOBt $(11.5 \mathrm{mg}, 0.075$ $\mu \mathrm{mol})$ and DIC (11.7 $\mu \mathrm{L} ; 0.075 \mu \mathrm{mol})$ in $200 \mu \mathrm{L}$ DMF for $3 \mathrm{~h}$, followed by Fmoc deprotection with 10\% 1,8-diazabicyclo-[5.4.0] undec-7-ene (DBU; Sigma-Aldrich; $v / v$ ) and $10 \%(\mathrm{~V} / \mathrm{V})$ piperidine in $1 \mathrm{~mL} \mathrm{DMF}$ ( 2 and $10 \mathrm{~min}$, respectively), and a $3 \mathrm{~h}$ manual coupling of Fmoc-L-Glu-OtBu (31.9 mg, $0.75 \mu \mathrm{mol})$ applying again HOBt $(11.5 \mathrm{mg}, 0.075 \mu \mathrm{mol})$ and DIC $(11.7 \mu \mathrm{L}, 0.075 \mu \mathrm{mol})$ in $200 \mu \mathrm{L}$ DMF. Subsequent Fmoc removal with 10\% $(v / v)$ DBU and $10 \%(\mathrm{~V} / \mathrm{V})$ piperidine in $1 \mathrm{~mL} \mathrm{DMF} \mathrm{(2} \mathrm{and} 10 \mathrm{~min}$, respectively) allowed acylation with fatty acids within $3 \mathrm{~h}$. Propanoic acid $(\mathbf{9}, \mathbf{1 5 a} ; 5.6 \mu \mathrm{L}, 0.075 \mu \mathrm{mol}$; Sigma-Aldrich), caprylic/ octanoic acid (10, 16a; $11.9 \mu \mathrm{L}, 0.075 \mu \mathrm{mol}$; Sigma-Aldrich) and lauric/dodecanoic acid (11, 17; $15 \mathrm{mg}, 0.075 \mu \mathrm{mol}$; Sigma-Aldrich) were reacted with HOBt (11.5 mg, $0.075 \mu \mathrm{mol})$ and DIC (11.7 $\mu \mathrm{L} ; 0.075 \mu \mathrm{mol})$ in $200 \mu \mathrm{L}$ DMF, while palmitic/hexadecanoic (12, 18a; 19.2 $\mathrm{mg}, 0.075 \mu \mathrm{mol})$ and arachidic/eicosanoic acid $(\mathbf{1 3}, \mathbf{1 9}$; $11.7 \mathrm{mg}, 0.075 \mu \mathrm{mol}$; Sigma-

Aldrich) were incubated with reactants in NMP. Dde removal was performed as described above, followed by automated peptide elongation to $\left[\mathrm{K}^{22}(\mathrm{E}-\mathrm{Lip})\right] \mathrm{hPP}_{2-36}$ or $\left[\mathrm{K}^{30}(\mathrm{E}-\right.$ $\mathrm{Lip})] \mathrm{hPP}_{2-36}$ respectively. Finally, lipidated compounds were cleaved from the resin with TFA $(900 \mu \mathrm{L})$ and a scavenger mixture of EDT $(70 \mu \mathrm{L})$ and TA $(30 \mu \mathrm{L})$ within $3 \mathrm{~h}$. Methionine reduction and subsequent dilution was performed as reported for $\mathbf{1 a}, \mathbf{8}$ and $\mathbf{1 4 a}$. For arachidoyl-modified compounds $(\mathbf{1 3}, \mathbf{1 9})$, the scale was halved to $7.5 \mu \mathrm{mol}$ effecting all described amounts of reagents. Purification was performed with a preparative Jupiter $10 \mathrm{u}$ Proteo RP-C ${ }_{18}$ HPLC column (90 ̊, $7.78 \mu \mathrm{m}, 250 \times 21.2 \mathrm{~mm}$; Phenomenex) using linear gradients of eluent B in A: $20 \%$ to $60 \%(\mathrm{~V} / \mathrm{V})$ in $40 \mathrm{~min}$ for $\mathbf{9}, \mathbf{1 0}, \mathbf{1 5 a}, \mathbf{1 6 a}, 20 \%$ to $70 \%$ $(\mathrm{v} / \mathrm{V})$ in $40 \mathrm{~min}$ for 11, 12, 17, 18a and $30 \%$ to $80 \%(\mathrm{v} / \mathrm{v})$ in $40 \mathrm{~min}$ for $\mathbf{1 3}$ and 19. Yield, purities, RP-HPLC and MALDI-TOF data are shown in Table 1.

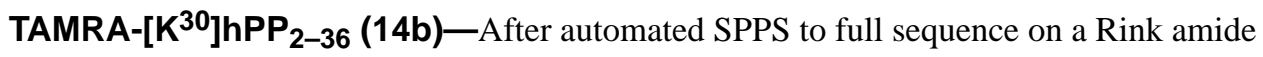
AM (14b) resin (7.5 $\mu$ mol scale), the peptide was N-terminally modified with TAMRA ( 9.7 $\mathrm{mg}, 0.023 \mu \mathrm{mol}$; emp Biotech, Berlin, Germany) by reaction of $O$-(7-azabenzotriazole-1yl)-1,1,3,3-tetramethyluronium-hexafluorophosphate (HATU; $8.6 \mathrm{mg}, 0.023 \mu \mathrm{mol}$; Novabiochem) and DIPEA ( $3.9 \mu \mathrm{L}, 0.023 \mu \mathrm{mol})$ in $100 \mu \mathrm{L}$ DMF for $3 \mathrm{~h}$ in the dark. The peptide was cleaved from the resin, reduced as described for CF-labeled compounds, dissolved in $\mathrm{H}_{2} \mathrm{O} / \mathrm{tBuOH}(1: 3, v / V)$ and lyophilized. Purification was performed with a preparative Jupiter 10u Proteo RP-C 18 HPLC column (90 Å, $7.78 \mu \mathrm{m}, 250 \times 21.2 \mathrm{~mm}$; Phenomenex) using a linear gradient of $20 \%$ to $60 \%(\mathrm{~V} / \mathrm{V})$ of eluent B in A over $40 \mathrm{~min}$. Steps after incorporation of the fluorophore were performed in the dark. Yield, purities, RPHPLC and MALDI-TOF characterization are listed in Table 3.

$\mathrm{K}^{\mathbf{3 0}}$ (TAMRA)]hPP $\mathbf{2}_{\mathbf{3 6}}(\mathbf{2 0}$ - - The peptide was fully synthesized by robot-assisted peptide synthesis on a NovaSyn TGR R resin (15 $\mu \mathrm{mol}$ scale) including a $3 \mathrm{~h}$ manual coupling step of Fmoc-L-Lys(Dde)-OH (40 mg, $0.075 \mu \mathrm{mol})$ with HOBt $(11.5 \mathrm{mg}, 0.075 \mu \mathrm{mol})$ and DIC $(11.7 \mu \mathrm{L} ; 0.075 \mu \mathrm{mol})$ in $200 \mu \mathrm{L}$ DMF at position 30. The N-terminal L-Ala was Bocprotected allowing selective lysine side chain modification. After Dde removal as mentioned above, lysine was modified with TAMRA (19.4 mg, $0.045 \mu \mathrm{mol})$ applying HATU $(17.1 \mathrm{mg}$, $0.045 \mu \mathrm{mol})$ and DIPEA $(7.7 \mu \mathrm{L}, 0.045 \mu \mathrm{mol})$ in $200 \mu \mathrm{L}$ DMF for $3 \mathrm{~h}$ in the dark. Resin cleavage and methionine reduction was carried out as described for 1a. Finally, the peptide 
was dissolved in $\mathrm{H}_{2} \mathrm{O} / t \mathrm{BuOH}(1: 3, V / v)$ and lyophilized. Purification was performed with a preparative Jupiter 10u Proteo RP-C 18 HPLC column (90 Å, $7.78 \mu \mathrm{m}, 250 \times 21.2 \mathrm{~mm}$; Phenomenex) using linear gradients of $20 \%$ to $60 \%(\mathrm{~V} / \mathrm{V})$ of eluent B in A over $40 \mathrm{~min}$. Steps after incorporation of the fluorophore were performed in the dark. Yield, purity, RPHPLC and MALDI-TOF characterization are listed in Table 3.

TAMRA-[K ${ }^{30}$ (E-Prop)]hPP $2-36$ (15b), TAMRA-[K ${ }^{30}$ (E-Prop)]hPP ${ }_{2-36}(16 b)$ and TAMRA-[K ${ }^{\mathbf{3 0}}$ (E-Pam)]hPP $\mathbf{2}_{\mathbf{3 6}} \mathbf{( 1 8 b )}$-SPPS was performed automatically up to $\mathrm{hPP}_{31-36}$ on a Rink amide AM resin (7.5 $\mu \mathrm{mol}$ scale). Dde-L-Lys(Fmoc)-OH (20.0 mg, $0.038 \mu \mathrm{mol})$ was coupled to the peptide using $\mathrm{HOBt}(5.8 \mathrm{mg}, 0.038 \mu \mathrm{mol})$ and DIC $(5.9 \mu \mathrm{L}$; $0.038 \mu \mathrm{mol})$ in $100 \mu \mathrm{L} \mathrm{DMF}$ for $3 \mathrm{~h}$, followed by Fmoc removal with $10 \%(\mathrm{v} / \mathrm{V}) \mathrm{DBU}$ and $10 \%(\mathrm{~V} / \mathrm{V})$ piperidine in DMF ( $1 \mathrm{~mL} ; 2$ and $10 \mathrm{~min}$, respectively) as well as a $3 \mathrm{~h}$ manual coupling of Fmoc-L-Glu-OtBu $(16.0 \mathrm{mg}, 0.038 \mu \mathrm{mol})$ with the same HOBt/DIC-activation mixture in DMF $(100 \mu \mathrm{L})$. Fmoc deprotection with 10\% $(v / v)$ DBU and 10\% $(v / v)$ piperidine enabled acylation with fatty acids within $3 \mathrm{~h}$. Propanoic acid $(\mathbf{1 5 b} ; 2.8 \mu \mathrm{L}, 0.038$ $\mu \mathrm{mol})$, caprylic acid $(\mathbf{1 6 b} ; 6.0 \mu \mathrm{L}, 0.038 \mu \mathrm{mol})$ or palmitic acid $(\mathbf{1 8 b} ; 9.6 \mathrm{mg}, 0.038 \mu \mathrm{mol})$ were reacted with $\mathrm{HOBt}(5.8 \mathrm{mg}, 0.038 \mu \mathrm{mol})$ and DIC $(5.9 \mu \mathrm{L} ; 0.038 \mu \mathrm{mol})$ in $100 \mu \mathrm{L}$ DMF. Dde removal was performed as described above, followed by automated peptide elongation to full sequence. Lipidated compounds were N-terminally labeled with TAMRA ( $9.7 \mathrm{mg}, 0.023 \mu \mathrm{mol})$ by reaction of HATU $(8.6 \mathrm{mg}, 0.023 \mu \mathrm{mol})$ and DIPEA ( $3.9 \mu \mathrm{L}, 0.023$ $\mu \mathrm{mol})$ in $100 \mu \mathrm{L}$ DMF for $3 \mathrm{~h}$ in the dark, cleaved from resin, reduced as described for CFlabeled compounds, dissolved in $\mathrm{H}_{2} \mathrm{O} / \mathrm{tBuOH}(1: 3, v / v)$ and lyophilized. Purification was performed with a preparative Jupiter 10u Proteo RP- $\mathrm{C}_{18}$ HPLC column (90 А, $7.78 \mu \mathrm{m}$, $250 \times 21.2 \mathrm{~mm}$; Phenomenex) using a linear gradient of $20 \%$ to $60 \%(\mathrm{v} / \mathrm{v})$ of eluent B in A over $40 \mathrm{~min}$. Steps after incorporation of the fluorophore were performed in the dark. Yield, purities, RP-HPLC and MALDI-TOF characterization can be found in Table 3.

\section{Radioligand binding studies}

African green monkey kidney (COS-7) cells were cultured in Dulbecco's modified Eagle's medium (DMEM; PAA) with $4.5 \mathrm{gL}^{-1}$ glucose and L-glutamine supplemented with $10 \%$ $(\mathrm{V} / \mathrm{V})$ heat-inactivated fetal calf serum (FCS; PAA), 100 units $\mathrm{ml}^{-1}$ penicillin (Invitrogen) and $100 \mu \mathrm{g} \mathrm{mL}-1$ streptomycin (Invitrogen) in a humidified atmosphere at $37^{\circ} \mathrm{C}$ and $5 \%$ $\mathrm{CO}_{2}$. For transfection, cells were grown to $60-70 \%$ confluence in $25 \mathrm{~cm}^{[2]}$ cell culture flasks and treated with $13 \mu \mathrm{g} \mathrm{hY}{ }_{4} \mathrm{R}-\mathrm{CFP}-\mathrm{N} 1 \mathrm{cDNA}^{[40]}$ and $13 \mu \mathrm{L}$ Lipofectamine2000 (Invitrogen) in OptiMEM reduced serum medium ( $2.5 \mathrm{~mL}$; Gibco) for $1 \mathrm{~h}$. After aspirating DNA/lipid solutions, cells were maintained in normal culture medium $(5 \mathrm{~mL}) .24 \mathrm{~h}$ after transient transfection, COS-7 cells were collected and resuspended in minimal essential medium (MEM; PAA) without L-glutamine, containing $1 \%(\mathrm{w} / \mathrm{V})$ bovine serum albumin (BSA; PAA) and $5 \mathrm{~mm}$ pefabloc (Sigma-Aldrich). For the radioligand binding assay, 70000 of transiently transfected COS-7 cells (200 $\mu \mathrm{L}$ per tube) were treated for $90 \mathrm{~min}$ at RT with $1 \mathrm{~nm}\left[{ }^{3} \mathrm{H}\right]-$ propionylated hPP $\left(\left[{ }^{3} \mathrm{H}\right]-\mathrm{hPP}\right)\left(25 \mu \mathrm{L}\right.$ per tube) solution and either $1 \%(\mathrm{v} / \mathrm{V}) \mathrm{BSA}$ in $\mathrm{H}_{2} \mathrm{O}$ (for total binding), or $1 \mu \mathrm{M}$ cold hPP or peptide analogue $(25 \mu \mathrm{L}$ per tube; for unspecific binding), respectively. $\left[{ }^{3} \mathrm{H}\right]-\mathrm{hPP}$ with a specific activity of $95 \mathrm{Ci} \mathrm{mmol}^{-1}$ was obtained by selective radiolabeling as published. ${ }^{[41]}$ Incubation was terminated by centrifugation $\left(4^{\circ} \mathrm{C}\right.$, $3200 \mathrm{rpm}, 5 \mathrm{~min})$. Cell pellets were washed twice with ice-cold phosphate buffered saline 
(PBS; PAA) (400 $\mu \mathrm{L}$ per tube), resuspended in PBS (100 $\mu \mathrm{L}$ per tube) and finally mixed with $3 \mathrm{~mL}$ scintillation cocktail (PerkinElmer). Radioactivity was measured using a betacounter (Tri-Carb 2910 TR, PerkinElmer). In order to examine IC $_{50}$ values (concentration of half-maximal inhibition) of selected analogues, dilution series were prepared in a range of $10^{-4}-10^{-10} \mathrm{M}$ and incubated and processed as described above. $\mathrm{IC}_{50}$ values were calculated by nonlinear regression assuming one-site competition using GraphPad Prism 5.0. Experiments were performed in triplicate and repeated three times. Statistical analysis was performed by one-way ANOVA, followed by Dunnett's post-hoc test and referred to total binding ( $* P \leq 0.05, * * P \leq 0.01$, *** $P \leq 0.001)$ using GraphPad Prism 5.0.

\section{Inositol phosphate accumulation assays}

For signal transduction assays, COS-7 cells stably expressing the respective hYR subtypes and a chimeric $\mathrm{G}_{\mathrm{i} / \mathrm{q}}$ protein (kindly provided by E. Kostenis, Universität Bonn) were generated as follows. COS-7 cells were co-transfected with linearized $\mathrm{hY}_{1 / 2 / 4 / 5}$-EYFPpVitro2-hygro-mcs vector $(2 \mu \mathrm{g})$ and linearized $\mathrm{G}_{\Delta 6 q i 4 m y r}$-pVitro2-neo-mcs ${ }^{[23]}(2 \mu \mathrm{g})$ using $12 \mu \mathrm{L}$ Metafectene (Biontex) transfection reagent according to the manufacturer's protocol. Three days post-transfection, selection was started using $1.5 \mathrm{mgmL}^{-1} \mathrm{G} 418$-sulfate (amresco) and $146 \mathrm{\mu gmL}^{-1}$ hygromycin B (Invivogen). Cell lines were raised from single colonies. Cultivation of stable COS-7-hYR-Ga ${ }_{\Delta 6 q i 4 m y r}$ cells was achieved in a humidified atmosphere at $37^{\circ} \mathrm{C}$ and $5 \% \mathrm{CO}_{2}$. Cells were maintained in DMEM with $4.5 \mathrm{gL}^{-1}$ glucose and L-glutamine supplemented with $10 \%(\mathrm{~V} / \mathrm{V})$ heat-inactivated FCS, 100 units ml $^{-1}$ penicillin, $100 \mu \mathrm{g} \mathrm{mL}^{-1}$ streptomycin, $1.5 \mathrm{mgmL}^{-1} \mathrm{G} 418$-sulfate and $146 \mu \mathrm{gmL}^{-1}$ hygromycin B. To determine ligand-induced IP accumulation, stably transfected COS-7 cells were seeded into 48 -well plates (70000 cells in $500 \mu \mathrm{L}$ per well) and grown for $24 \mathrm{~h}$. Subsequently, cells were labeled with $2 \mu \mathrm{CimL}^{-1}$ myo-[2- $\left.{ }^{3} \mathrm{H}\right]$-inositol (PerkinElmer) in culture medium $(150 \mu \mathrm{L}$ per well) without penicillin and streptomycin for at least $16 \mathrm{~h}$, washed $\left(250 \mu \mathrm{L}\right.$ per well) and stimulated for $1 \mathrm{~h}$ at $37^{\circ} \mathrm{C}(150 \mu \mathrm{L}$ per well) with peptides at concentrations ranging from $10^{-4}$ to $10^{-12} \mathrm{M}$ (depending on expected potency) in FCS-free DMEM with $4.5 \mathrm{gL}^{-1}$ glucose and L-glutamine containing $10 \mathrm{~mm} \mathrm{LiCl} \mathrm{(Sigma-Aldrich).}$ Next, cells were lysed with $\mathrm{NaOH}(0.1 \mathrm{~N}, 100 \mu \mathrm{L}$ per well; Grossing, Filsum, Germany) for $5 \mathrm{~min}$, neutralized by addition of formic acid $(0.13 \mathrm{M}, 50 \mu \mathrm{L}$ per well; Grossing) and finally diluted in sodium borate ( $5 \mathrm{~mm}$; Merck)/ethylenediaminetetraacetic acid (EDTA; $0.5 \mathrm{~mm}$; Applichem) buffer ( $750 \mu \mathrm{L}$ per well). Cell debris was removed, and samples were loaded on a fresh or regenerated anion exchange resin (AG 1-X8 formate, BIO-RAD; $500 \mathrm{mg}$ per column). After column washing with glycerophosphate elution buffer ( $5 \mathrm{~mm}$ sodium borate, $60 \mathrm{~mm}$ sodium formate (Sigma-Aldrich); $5 \mathrm{~mL}$ per column) and $\mathrm{H}_{2} \mathrm{O}$ ( $5 \mathrm{~mL}$ per column), radioactive phosphoinositides were eluted with $1 \mathrm{~mm}$ ammonium formate (Paul Lohmann) buffer containing $0.1 \mathrm{~m}$ formic acid $(1.25 \mathrm{~mL}$ per well), mixed with $3 \mathrm{~mL}$ scintillation cocktail and measured using a betacounter (Tri-Carb 2910 TR). Decay-per-minute values at the highest used analogue concentration were normalized to the mean value of the respective wild type at full activity concentration. Collected normalized data were analyzed by nonlinear regression of all datasets using GraphPad Prism 5.0 revealing global mean $\mathrm{EC}_{50}$ and $\mathrm{pEC}_{50}$ values as well as mean efficacies given with \pm SEM. All compounds were investigated in duplicate by at least two independent experiments. 


\section{Circular dichroism (CD) spectroscopy}

$\mathrm{CD}$ spectra of $10 \mu \mathrm{M}$ peptide solutions were recorded on a Jasco-715 spectropolarimeter with a constant nitrogen stream at $22{ }^{\circ} \mathrm{C} .10 \mathrm{~mm}$ sodium phosphate (Sigma-Aldrich) buffer supplemented with or without $20 \mathrm{~mm}$ SDS (Carl Roth) served as buffer solutions (pH 7.0). Measurements in the far UV region between $190 \mathrm{~nm}$ and $250 \mathrm{~nm}$ were conducted with a cuvette of $2 \mathrm{~mm}$ path length and the following parameters: 100 mdeg sensitivity, $0.5 \mathrm{~nm}$ data pitch, continuous scanning mode, $50 \mathrm{~nm} \mathrm{~min}{ }^{-1}$ scanning speed, $4 \mathrm{~s}$ response, $2 \mathrm{~nm}$ bandwidth and 6 accumulations. Compound concentration was calculated from aromatic absorption of the examined peptide aliquots in aqueous solution using the molar extinction coefficient at $280 \mathrm{~nm}\left(\varepsilon=5960 \mathrm{M}^{-1} \mathrm{~cm}^{-1}\right)$. Obtained CD spectra were baseline corrected in order to subtract buffer effects and converted into mean residue molar ellipticity $[\Theta]$ given in deg $\mathrm{cm}^{2} \mathrm{dmol}^{-1}$ by the equation: $[\Theta]=(\Theta \times M) /(10 \times c \times 1 \times n) . \Theta$ corresponds to the ellipticity in mdeg, $M$ is the compound molar mass in $\mathrm{gmol}^{-1}, c$ is the concentration in $\mathrm{mgmL}^{-1}, l$ is the path length of the cuvette in $\mathrm{cm}$ and $n$ is the number of peptide bond residues. All experiments were performed twice independently. $a$-Helical contents were calculated by Dichroweb applying K2D estimation. ${ }^{[22]}$ Statistical significance was determined by one way-ANOVA, followed by Dunnett's post-hoc test and referred to respective $\left[\mathrm{K}^{\mathrm{h}} \mathrm{hPP}_{2-36}\right.$ lead compounds (**P $\leq 0.01, * * * P \leq 0.001)$ using GraphPad Prism 5.0.

\section{Stability tests in human blood plasma}

In order to follow enzymatic degradation of TAMRA-modified analogues, the peptides (15 nmol) were freshly reduced by dilution in $100 \mu \mathrm{L}$ TFA and treatment with $3 \mu \mathrm{L}$ TMSBr and $3 \mu \mathrm{L}$ EDT for $30 \mathrm{~min}$. After precipitation from $1 \mathrm{~mL}$ ice-cold $\mathrm{Et}_{2} \mathrm{O}$ for $20 \mathrm{~min}$, they were washed and re-suspended further three times with $\mathrm{Et}_{2} \mathrm{O}$ and dried in vacuo. Then, peptide aliquots were diluted to $10 \mu \mathrm{m}$ in human blood plasma and incubated at $37^{\circ} \mathrm{C}$ with mechanical shaking at $500 \mathrm{rpm}$. Individual samples $(150 \mu \mathrm{L})$ were taken after $0,24,48,72$, 96, 120 and $144 \mathrm{~h}$, and precipitation of proteins was performed with $150 \mu \mathrm{L} \mathrm{CH}_{3} \mathrm{CN} / \mathrm{EtOH}$ $\left(1: 1, v / v\right.$, Applichem) at $-20^{\circ} \mathrm{C}$ for $3 \mathrm{~h}$. After centrifugation (RT, $14000 \mathrm{rpm}, 30 \mathrm{~s}$ ), supernatants were processed in Costar Spin-X tubes $(0.22 \mu \mathrm{m}$ membrane pore size $)$ for HPLC analysis. A Varian-VariTide RPC column (200 ̊, $6 \mu \mathrm{m}, 250 \times 4.6 \mathrm{~mm})$ with fluorescence detection ( $\lambda_{\mathrm{ex}}: 525 \mathrm{~nm}, \lambda_{\mathrm{em}}: 572 \mathrm{~nm}$ ) was used with a linear gradient of $5 \%$ to $60 \%(\mathrm{~V} / \mathrm{V})$ of eluent B in A over $45 \mathrm{~min}$. Quantity of intact peptide-specific fluorescence was calculated as proportion of control at $0 \mathrm{~h}(100 \%)$. The first data points revealed an exponential decay that allowed determination of half-lives $\left(t_{1 / 2}\right)$ according to an enzymatic degradation of first order. For each compound, every single time point was analyzed independently at least twice and is presented as the mean \pm SEM. Statistical significance of $t_{1 / 2}$ values was determined by one-way ANOVA, followed by Dunnett's post-hoc test with comparison to control peptide 14b $(* * P \leq 0.01, * * * P \leq 0.001)$ using GraphPad Prism 5.0.

\section{Metabolic stability in porcine liver homogenates}

Porcine liver $(50 \mathrm{~g})$ was hackled and homogenized in PBS $(200 \mathrm{~mL})$ and centrifuged $\left(4^{\circ} \mathrm{C}\right.$, $5000 \mathrm{rpm}, 30 \mathrm{~min})$. The supernatant was aliquoted and frozen at $-70^{\circ} \mathrm{C}$. Degradation of fluorescently labeled peptides (10 $\mu \mathrm{m}$ final concentration) that were dissolved in $15 \mu \mathrm{L} \mathrm{H}_{2} \mathrm{O}$ / $t \mathrm{BuOH}(1: 3, v / v)$ was initiated by addition of $50 \mathrm{mgmL}^{-1}$ homogenized liver solution in 
PBS (1.5 mL final volume). Reaction tubes were kept at $37^{\circ} \mathrm{C}$ and mechanical shaking at $500 \mathrm{rpm}$. Samples $(150 \mu \mathrm{L})$ were taken after $0,2,4,6,8,12,24,36$ and $48 \mathrm{~h}$, processed and analyzed as described for the human blood plasma assay. For each compound, every single time point was analyzed independently at least twice and is shown as the mean $\pm \mathrm{SEM}$. Statistical analysis of $t_{1 / 2}$ values was calculated by one-way ANOVA, followed by Dunnett's post-hoc test and referred to the parent peptide 14b $(* * P \leq 0.01)$ using GraphPad Prism 5.0.

\section{Acknowledgments}

The authors thank Jan-Patrick Fischer and Andrea Kindermann for experimental assistance. Regina ReppichSacher, Kristin Löbner and Christina Dammann (Universität Leipzig) are kindly acknowledged for their excellent help in mass spectrometry, cell culture and peptide synthesis. The authors gratefully thank for financial support from the European Union, "Gastro-intestinal peptides in obesity" (GIPIO), FP7 (No. 223057), the US National Institutes of Health (NIH) (GM077561 and DK097376), the Deutsche Forschungsgemeinschaft (DFG) (BE1264/16) and the Leipzig Graduate School BuildMoNa. Helpful discussions with all GIPIO collaborators are kindly acknowledged.

\section{References}

1. Adrian TE, Greenberg GR, Besterman HS, Bloom SR. Gut. 1978; 19:907-909. [PubMed: 568585]

2. a) Murphy KG, Bloom SR. Nature. 2006; 444:854-859. [PubMed: 17167473] b) Simpson, K., Parker, J., Plumer, J., Bloom, S. Handb Exp Pharmacol. Joost, HG., editor. Vol. 209. Springer; Heidelberg: 2012. p. 209-230.

3. Bard JA, Walker MW, Branchek TA, Weinshank RL. J Biol Chem. 1995; 270:26762-26765. [PubMed: 7592911]

4. Asakawa A, Inui A, Ueno N, Fujimiya M, Fujino MA, Kasuga M. Peptides. 1999; 20:1445-1448. [PubMed: 10698120]

5. a) Asakawa A, Inui A, Yuzuriha H, Ueno N, Katsuura G, Fujimiya M, Fujino MA, Niijima A, Meguid MM, Kasuga M. Gastroenterology. 2003; 124:1325-1336. [PubMed: 12730873] b) Batterham RL, Le Roux CW, Cohen MA, Park AJ, Ellis SM, Patterson M, Frost GS, Ghatei MA, Bloom SR. J Clin Endocrinol Metab. 2003; 88:3989-3992. [PubMed: 12915697]

6. Berntson GG, Zipf WB, O'Dorisio TM, Hoffman JA, Chance RE. Peptides. 1993; 14:497-503. [PubMed: 8332550]

7. Pedragosa-Badia X, Stichel J, Beck-Sickinger AG. Front Endocrinol. 2013; 4:5.

8. Greenwood HC, Bloom SR, Murphy KG. Rev Diabet Stud. 2011; 8:355-368. [PubMed: 22262073]

9. Yulyaningsih E, Zhang L, Herzog H, Sainsbury A. Br J Pharmacol. 2011; 163:1170-1202. [PubMed: 21545413]

10. Lean MEJ. Proc Nutr Soc. 2000; 59:331-336. [PubMed: 10997648]

11. a) Vlieghe P, Lisowski V, Martinez J, Khrestchatisky M. Drug Discovery Today. 2010; 15:40-56. [PubMed: 19879957] b) Mäde V, Els-Heindl S, Beck-Sickinger AG. Beilstein J Org Chem. 2014; 10:1197-1212. [PubMed: 24991269]

12. Yu JH, Kim MS. Diabetes Metab J. 2012; 36:391-398. [PubMed: 23275931]

13. Ahrens VM, Bellmann-Sickert K, Beck-Sickinger AG. Future Med Chem. 2012; 4:1567-1586. [PubMed: 22917246]

14. Zhang L, Bulaj G. Curr Med Chem. 2012; 19:1602-1618. [PubMed: 22376031]

15. Kurtzhals P, Havelund S, Jonassen I, Kiehr B, Larsen UD, Ribel U, Markussen J. Biochem J. 1995; 312:725-731. [PubMed: 8554512]

16. a) Dasgupta P, Singh A, Mukherjee R. Biol Pharm Bull. 2002; 25:29-36. [PubMed: 11824552] b) Wang J, Wu D, Shen WC. Pharm Res. 2002; 19:609-614. [PubMed: 12069162] c) Todorovic A, Holder JR, Bauzo RM, Scott JW, Kavanagh R, Abdel-Malek Z, Haskell-Luevano C. J Med Chem. 2005; 48:3328-3336. [PubMed: 15857138] d) Madsen K, Knudsen LB, Agersoe H, Nielsen PF, Thøgersen H, Wilken M, Johansen NL. J Med Chem. 2007; 50:6126-6132. [PubMed: 17975905] e) Zhang L, Robertson CR, Green BR, Pruess TH, White HS, Bulaj G. J Med Chem. 2009; 
52:1310-1316. [PubMed: 19199479] f) Agnihotri G, Crall BM, Lewis TC, Day TP, Balakrishna R, Warshakoon HJ, Malladi SS, David SA. J Med Chem. 2011; 54:8148-8160. [PubMed: 22007676]

17. Pedragosa-Badia X, Sliwoski GR, Dong Nguyen E, Lindner D, Stichel J, Kaufmann KW, Meiler J, Beck-Sickinger AG. J Biol Chem. 2014; 289:5846-5859. [PubMed: 24375409]

18. Gehlert DR, Schober DA, Beavers L, Gadski R, Hoffman JA, Smiley DL, Chance RE, Lundell I, Larhammar D. Mol Pharmacol. 1996; 50:112-118. [PubMed: 8700103] b) T. Schwartz, US2008/0269114A1, 30.10.2008.

19. Merrifield RB. J Am Chem Soc. 1963; 85:2149-2154.

20. a) Bellmann-Sickert K, Elling CE, Madsen AN, Little PB, Lundgren K, Gerlach LO, Bergmann R, Holst B, Schwartz TW, Beck-Sickinger AG. J Med Chem. 2011; 54:2658-2667. [PubMed: 21410292] b) Mäde V, Babilon S, Jolly N, Wanka L, Bellmann-Sickert K, Diaz Gimenez LE, Mörl K, Cox HM, Gurevich VV, Beck-Sickinger AG. Angew Chem Int Ed. 2014; doi: 10.1002/anie. 201403750

21. a) Schwartz TW, Fuhlendorff J, Kjems LL, Kristensen MS, Vervelde M, O'Hare M, Krstenansky JL, Bjørnholm B. Ann N Y Acad Sci. 1990; 611:35-47. [PubMed: 2174222] b) Lerch M, Gafner V, Bader R, Christen B, Folkers G, Zerbe O. J Mol Biol. 2002; 322:1117-1133. [PubMed: 12367532]

22. http://dichroweb.cryst.bbk.ac.uk/html/home.shtml (last accessed: May 2014).

23. Kostenis E, Degtyarev MY, Conklin BR, Wess J. J Biol Chem. 1997; 272:19107-19110. [PubMed: 9235898]

24. Greenfield NJ. Nat Protoc. 2007; 1:2876-2890.

25. Schwartz, T. Y2/Y4 Selective Receptor Agonists for Therapeutic Interventions. US Pat Appl US20080261871A1. Oct. 2008

26. Koulu M, Movafagh S, Tuohimaa J, Jaakkola U, Kallio J, Pesonen U, Geng Y, Karvonen MK, Vainio-Jylhä E, Pöllönen M, Kaipio-Salmi K, Seppälä H, Lee EW, Higgins RD, Zukowska Z. Ann Med. 2004; 36:232-240. [PubMed: 15181979]

27. Lu C, Everhart L, Tilan J, Kuo L, Sun CCJ, Munivenkatappa RB, Jonsson-Rylander AC, Sun J, Kuan-Celarier A, Li L, Abe K, Zukowska Z, Toretsky JA, Kitlinska J. Oncogene. 2010; 29:5630_ 5642. [PubMed: 20676138]

28. Degen L, Oesch S, Casanova M, Graf S, Ketterer S, Drewe J, Beglinger C. Gastroenterology. 2005; 129:1430-1436. [PubMed: 16285944]

29. Bjørnholm B, Jørgensen FS, Schwartz TW. Biochemistry. 1993; 32:2954-2959. [PubMed: 8457560]

30. a) Zwanziger D, Khan IU, Neundorf I, Sieger S, Lehmann L, Friebe M, Dinkelborg L, BeckSickinger AG. Bioconjugate Chem. 2008; 19:1430-1438.b) Ahrens VM, Frank R, Stadlbauer S, Beck-Sickinger AG, Hey-Hawkins E. J Med Chem. 2011; 54:2368-2377. [PubMed: 21395319]

31. Merten N, Lindner D, Rabe N, Rompler H, Mörl K, Schöneberg T, Beck-Sickinger AG. J Biol Chem. 2007; 282:7543-7551. [PubMed: 17204471]

32. Walker MW, Smith KE, Bard J, Vaysse PJ, Gerald C, Daouti S, Weinshank RL, Branchek TA. Peptides. 1997; 18:609-612. [PubMed: 9210181]

33. Haack M, Enck S, Seger H, Geyer A, Beck-Sickinger AG. J Am Chem Soc. 2008; 130:8326-8336. [PubMed: 18529062]

34. Hofmann S, Frank R, Hey-Hawkins E, Beck-Sickinger AG, Schmidt P. Neuropeptides. 2013; 47:59-66. [PubMed: 23352609]

35. Poschner BC, Langosch D. Protein Sci. 2009; 18:1801-1805. [PubMed: 19569191]

36. a) Knudsen LB, Nielsen PF, Huusfeldt PO, Johansen NL, Madsen K, Pedersen FZ, Thøgersen H, Wilken M, Agers $\varnothing$ H. J Med Chem. 2000; 43:1664-1669. [PubMed: 10794683] b) Ward BP, Ottaway NL, Perez-Tilve D, Ma D, Gelfanov VM, Tschöp MH, DiMarchi RD. Mol Metab. 2013; 2:468-479. [PubMed: 24327962]

37. Ashbrook JD, Spector AA, Santos EC, Fletcher JE. J Biol Chem. 1975; 250:2333-2338. [PubMed: 234968]

38. Spector AA. J Lipid Res. 1975; 16:165-179. [PubMed: 236351] 
39. Zou C, Kumaran S, Markovic S, Walser R, Zerbe O. ChemBioChem. 2008; 9:2276-2284. [PubMed: 18767100]

40. Böhme I, Stichel J, Walther C, Mörl K, Beck-Sickinger AG. Cell Signalling. 2008; 20:1740-1749. [PubMed: 18598760]

41. Koglin N, Lang M, Rennert R, Beck-Sickinger AG. J Med Chem. 2003; 46:4369-4372. [PubMed: 14521401] 
a) H-APLEPVYYPG D NATPEQMAQYAADLRRYINMLTRPR Y-NH

b)

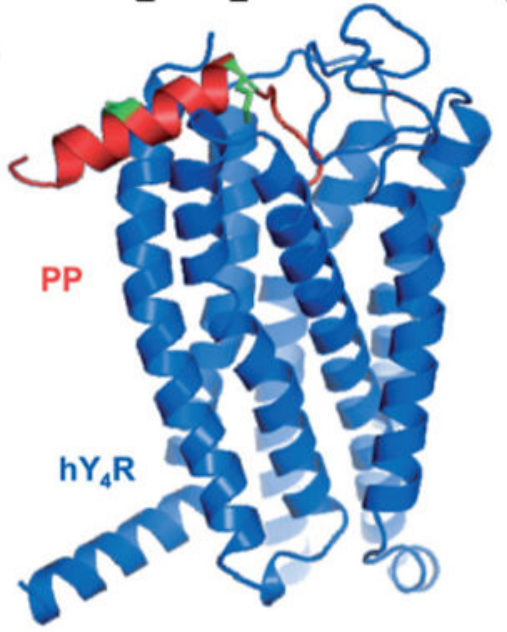

c)

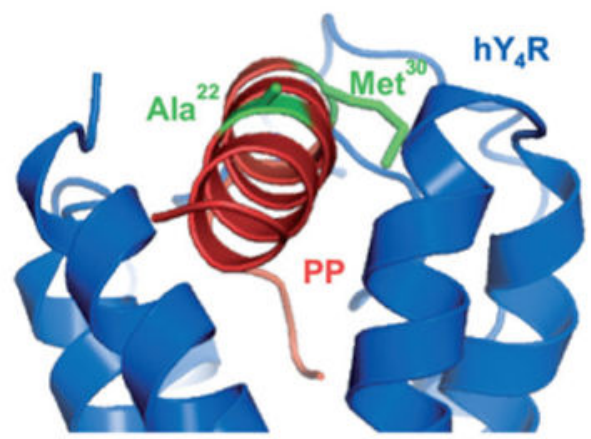

Figure 1.

a) Amino acid sequence of hPP; residues to be modified are underlined. b) Side view of the comparative model of human $\mathrm{Y}_{4} \mathrm{R}$ (blue) with docked bovine PP (red; PDB code:

$1 \mathrm{LJV}) ;{ }^{[21 \mathrm{~b}]}$ lipidated positions are indicated in green. ${ }^{[17]} \mathrm{c}$ ) Enlarged section of the same model obtained by horizontal rotation by approximately $90^{\circ}$; lipidated residues $\mathrm{Ala}^{22}$ and Met $^{30}$ appear green. 
a)

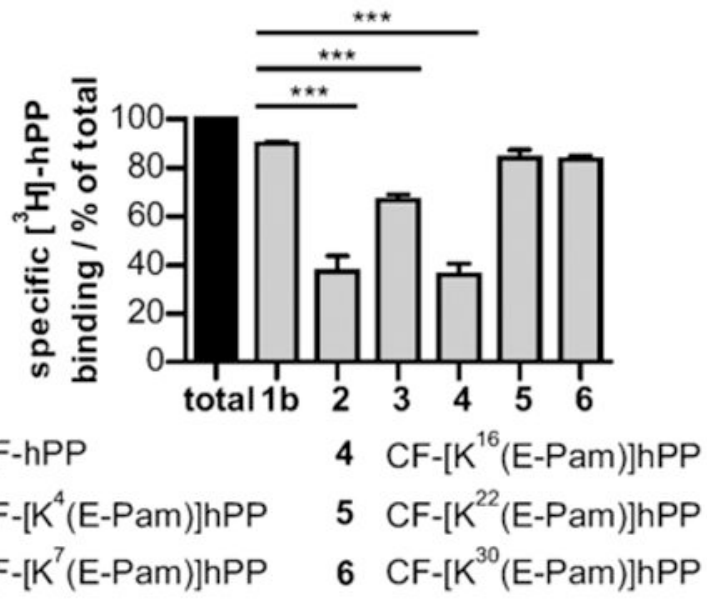

b)

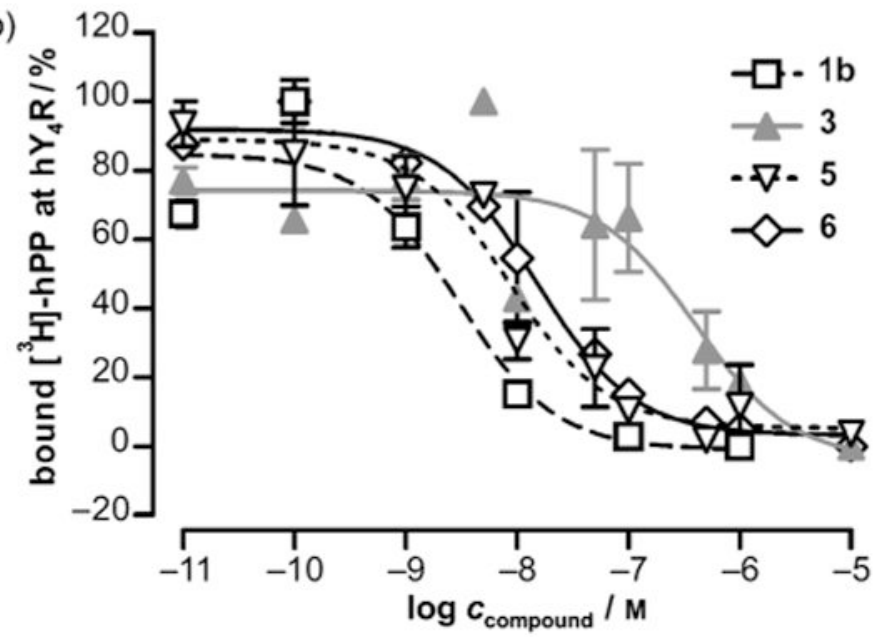

Figure 2.

a) First evaluation of the binding capacity by $1 \mu \mathrm{m}$ CF-labeled hPP analogues $\mathbf{1 b}, \mathbf{2 - 6}$ in transiently hY ${ }_{4} \mathrm{R}$-expressing COS-7 cells towards $\left[{ }^{3} \mathrm{H}\right]$-hPP after a 90 min stimulation period. Total binding was set to $100 \%$ and corresponds to binding of radioligand in presence of $\mathrm{H}_{2} \mathrm{O}$ in $1 \%(\mathrm{~W} / \mathrm{V}) \mathrm{BSA}$. Statistical analysis was performed by one-way ANOVA, followed by Dunnett's post-hoc test (GraphPad Prism 5.0). $* * * P \leq 0.001$, as compared to $\mathbf{1 b}$ (horizontal lines). b) For competition binding experiments, $\left[{ }^{3} \mathrm{H}\right]-\mathrm{hPP}$ was displaced by increasing concentrations of most promising analogues $1,3,5$ and $\mathbf{6}$. Assays were performed in triplicate; mean values \pm SEM of independently examined experiments are shown. 

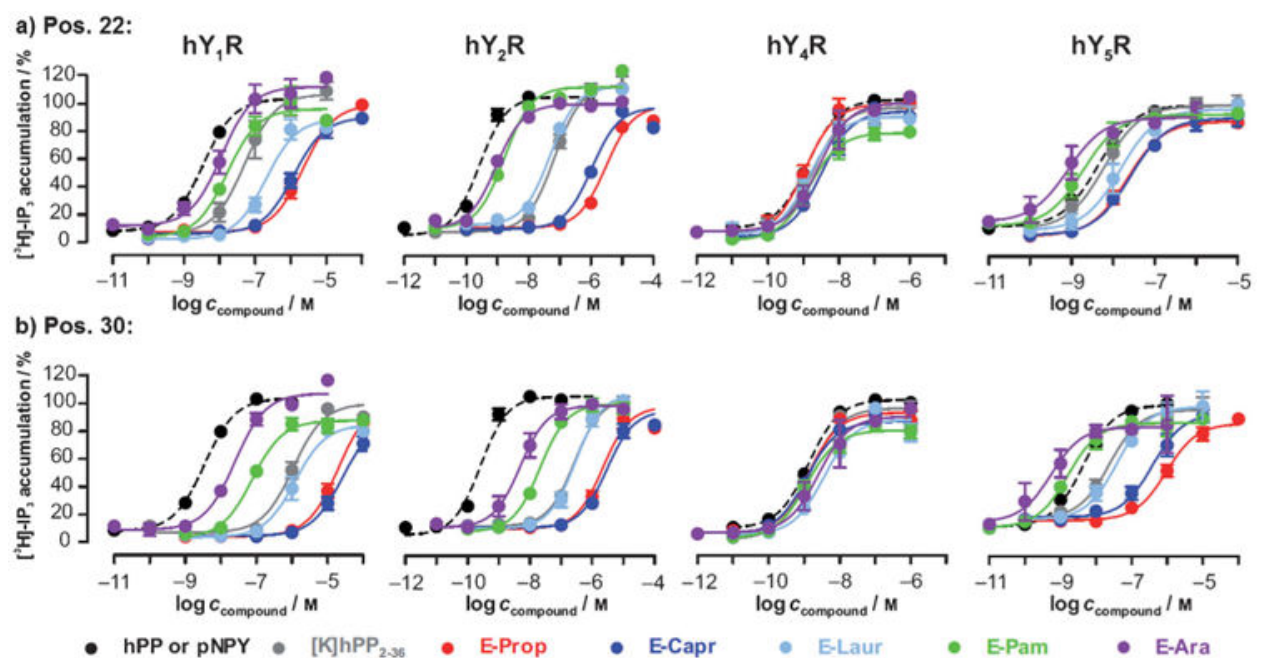

- hPP or pNPY - $\left[\mathrm{KJThP}_{2,36}\right.$ - E-Prop • E-Capr

- ELaur

- E-Pam - e-Ara

Figure 3.

Functional characterization of hPP compounds fatty acid acylated at a) position 22 and b) residue 30 at COS-7 cells stably expressing the anorexigenic $h Y_{4} R$ and $h Y_{2} R$ as well as the orexigenic $h Y_{1} R$ and $h Y_{5} R$. Co-expression of $h Y R$ and a chimeric $G_{i / q}$ protein allowed concentration-dependent radioactive inositol phosphate accumulation. Mean concentrationresponse curves of at least two independent experiments, fitted by non-linear regression (GraphPad Prism 5.0) are shown with \pm SEM. Dashed black lines correspond to the respective native ligands ( $h P P$ for $h Y_{4} R$ and porcine NPY (pNPY) for $h Y_{1} R, h Y_{2} R$ and $\mathrm{hY}_{5} \mathrm{R}$ ). 
a)
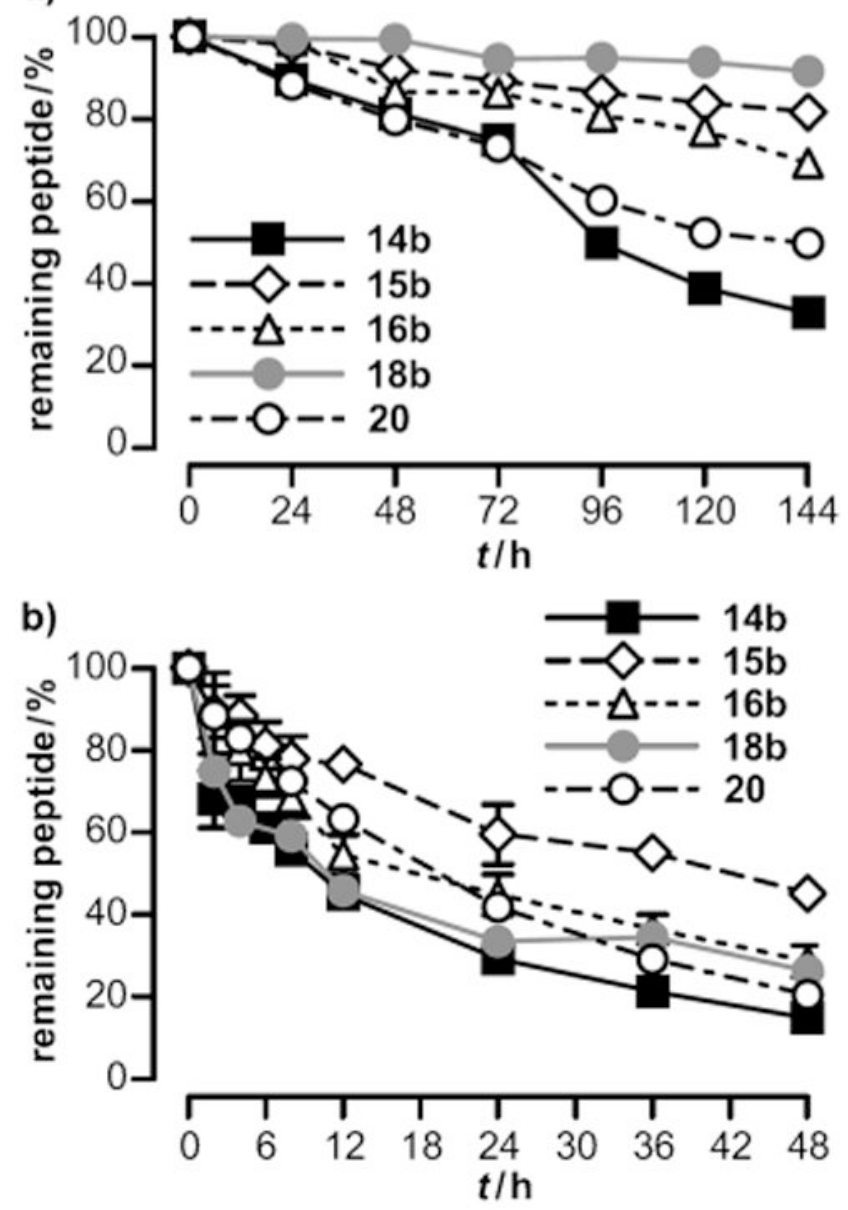

Figure 4.

In vitro stability tests of TAMRA-labeled $\mathrm{h} \mathrm{Y}_{4} \mathrm{R}$-selective lipidated $\mathrm{hPP}$ conjugates $(\mathbf{1 5 b}$, 16b) along with the Pam-variant (18b) and relevant control peptides (14b, 20) performed in a) human blood plasma and b) $50 \mathrm{mgmL}^{-1}$ porcine liver extract homogenates. $10 \mu \mathrm{m}$ peptide solutions were incubated at $37^{\circ} \mathrm{C}$ and $500 \mathrm{rpm}$. Degradation was followed using RP-HPLC at indicated time points by peptide-specific fluorescence monitoring and referred to control at $0 \mathrm{~h}(100 \%)$. Values are the mean \pm SEM of two independent experiments. 


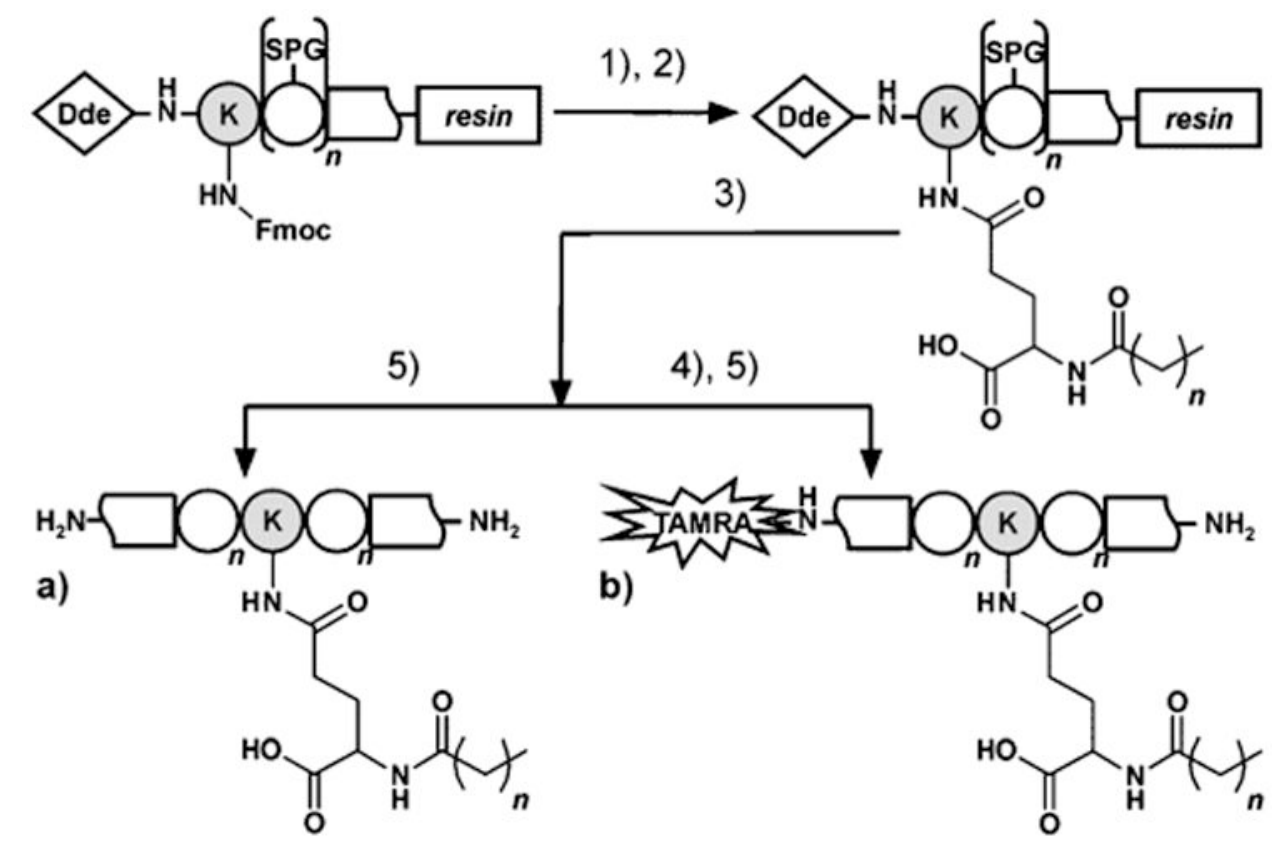

Scheme 1.

Synthesis of a) $[\mathrm{K}(\mathrm{E}-\mathrm{Lip})] \mathrm{hPP} \mathrm{P}_{2-36}$ and b) TAMRA-[K(E-Lip)]hPP $2-36$. Peptides were assembled by automated SPPS up to modification site (22 or 30), substituted with Lys (grey) that was protected by Fmoc at the $\gamma$-amino group and by Dde at the $\mathrm{N}$ terminus. 1) Fmoc removal and coupling of Fmoc-L-Glu-O $t \mathrm{Bu}$. 2) Fmoc deprotection and acylation with fatty acids (Lip): $\mathrm{C}_{2} \mathrm{H}_{5} \mathrm{COOH}$ (Prop) for 9, 15a, 15b; $\mathrm{C}_{7} \mathrm{H}_{15} \mathrm{COOH}$ (Capr) for 10, 16a, 16b; $\mathrm{C}_{11} \mathrm{H}_{23} \mathrm{COOH}$ (Laur) for 11, 17; $\mathrm{C}_{15} \mathrm{H}_{31} \mathrm{COOH}$ (Pam) for 12, 18a, 18b; $\mathrm{C}_{19} \mathrm{H}_{3} 9 \mathrm{COOH}$ (Ara) for 13, 19. 3) Dde removal and automated elongation to desired peptide sequence. 4) TAMRA-labeling of peptide $\mathrm{N}$ terminus. 5) Cleavage from resin including deprotection of all acid-labile side chain protecting groups (SPG) and methionine reduction. 


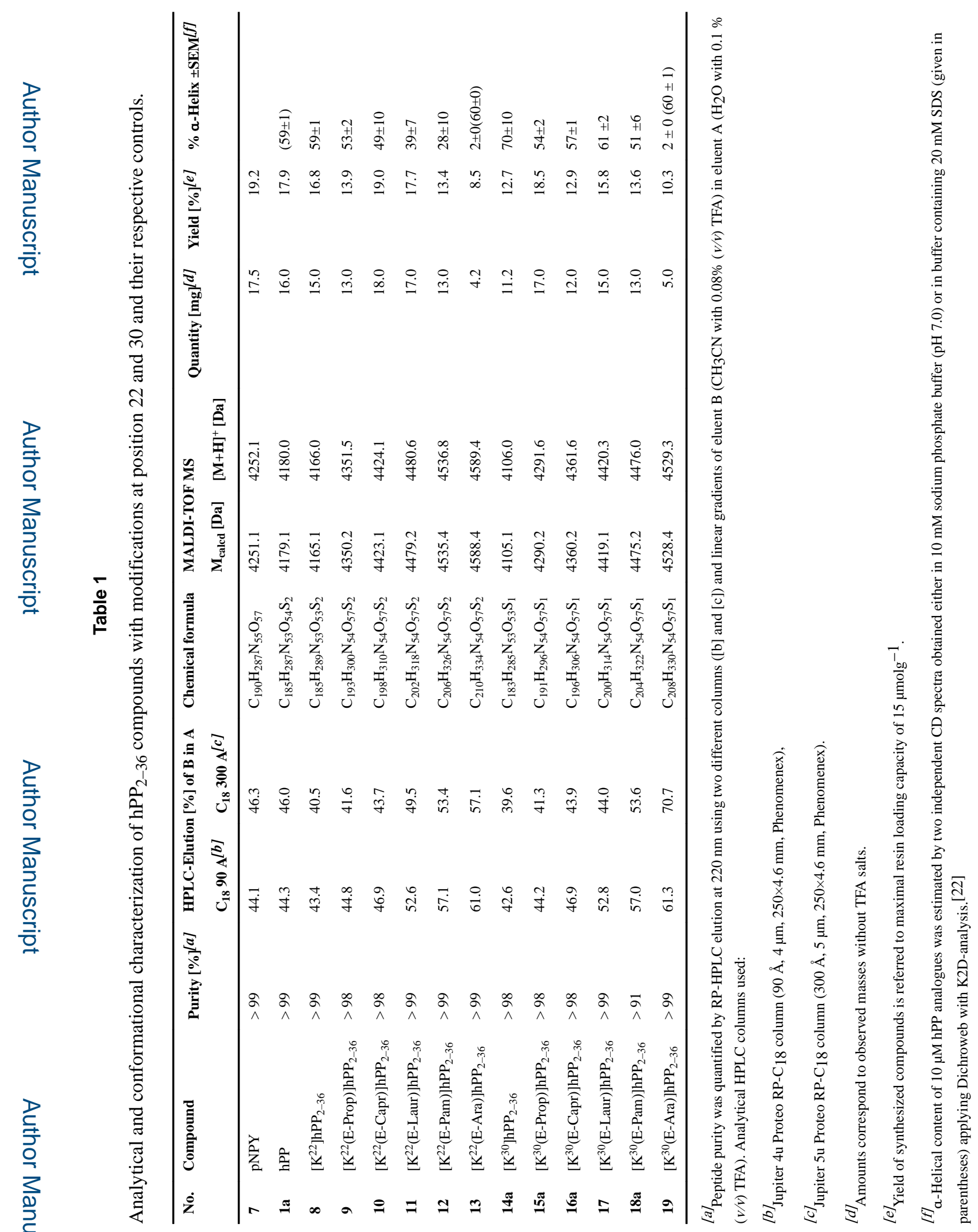

ChemMedChem. Author manuscript; available in PMC 2017 July 20. 


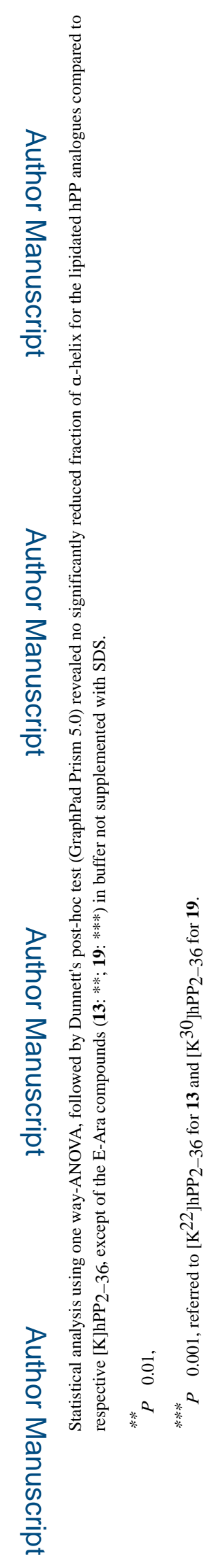




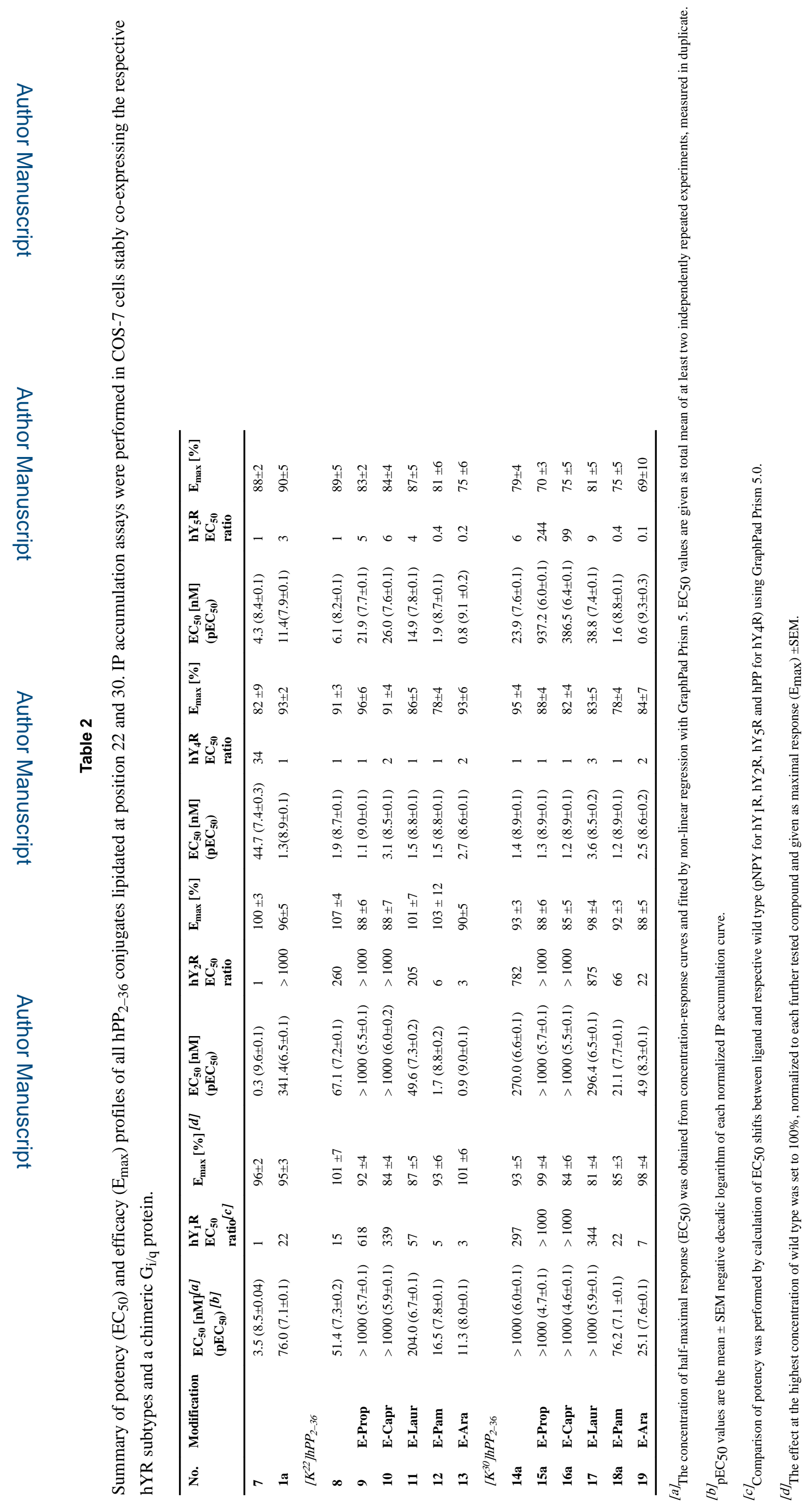




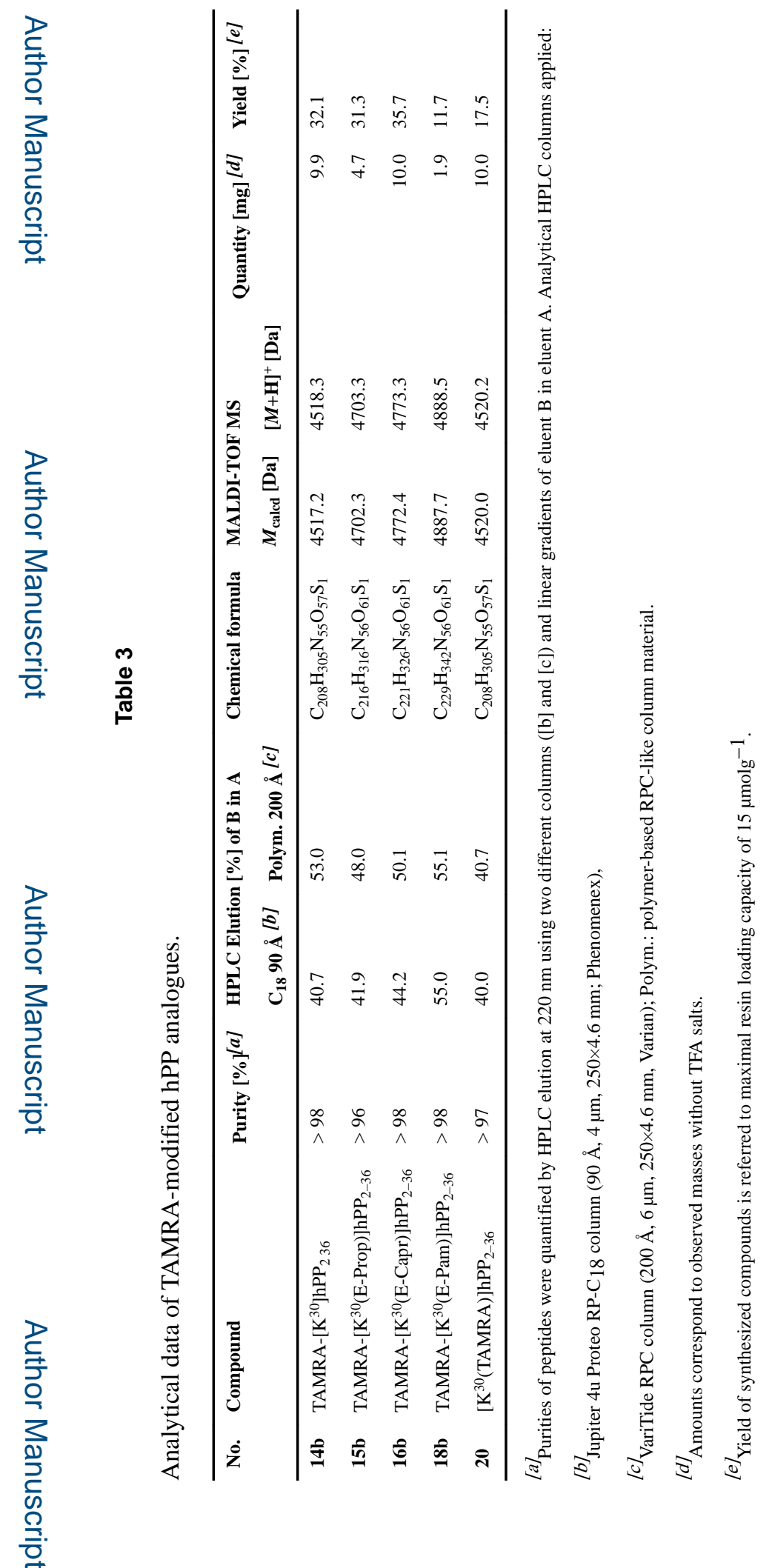

ChemMedChem. Author manuscript; available in PMC 2017 July 20. 


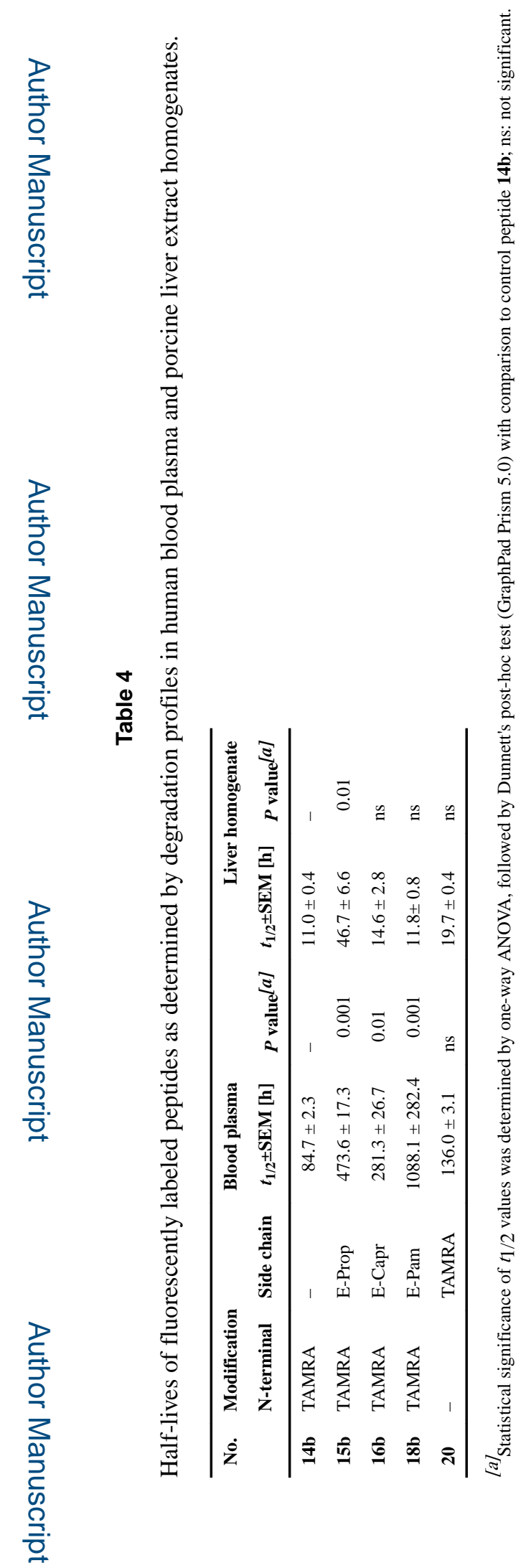

ChemMedChem. Author manuscript; available in PMC 2017 July 20. 